\title{
Effects of ocean climate on life cycles and distribution of small pelagic fishes in the California Current System off Baja California
}

\section{Efectos del clima oceánico sobre el ciclo de vida y la distribución de peces pelágicos menores en el Sistema de la Corriente de California, frente a Baja California}

\author{
José Augusto Valencia-Gasti ${ }^{1}$, Timothy Baumgartner ${ }^{2}$, Reginaldo Durazo ${ }^{1 *}$ \\ ${ }^{1}$ Facultad de Ciencias Marinas, Universidad Autónoma de Baja California, Carretera Tijuana-Ensenada \#3917, \\ Zona Playitas, CP 22860 Ensenada, Baja California, México \\ ${ }^{2}$ Departamento de Oceanografía Biológica, División de Oceanología, Centro de Investigación Científica y de \\ Educación Superior de Ensenada (CICESE), Carretera Ensenada-Tijuana \#3918, Zona Playitas, CP 22860 \\ Ensenada, Baja California, México \\ * Corresponding author. E-mail: rdurazo@uabc.edu.mx.
}

\begin{abstract}
Due to their sensitivity to climate forcing that may alter their abundance and distribution, small pelagic fish are important ecological indicators of the state of the California Current System. They are schooling, planktivorous fish that provide forage for higher trophic levels. We describe the life cycle histories and patterns of distribution of sardine, anchovy, and mackerel species occupying the waters along the west coast of the Baja California Peninsula (Mexico). The links between the physical and biological forcing and the structure and condition of their habitats, their patterns of movement, productivity, and stock structure (where information is available) are described in relation to the fisheries. We have used the catches as a proxy for the history of the different stocks, while recognizing that fisheries-derived information is biased by the operational scale and only covers areas where fish are available. We have relied mainly on studies of sardines to evaluate the validity of the principal paradigms in fisheries oceanography. We describe how the environment can structure a population by relating an example given by the spatiotemporal variability of the northern and southern stocks of Pacific sardine (Sardinops sagax) and Pacific mackerel (Scomber japonicus) from 2000 to 2014. During this period, the northern stocks showed a marked tendency to contract southwards, as far south as Magdalena Bay, in response to the regional cooling that began in the previous decade. It appears that the combined effects of fishing and climate change may sufficiently alter habitat characteristics so that both the distribution and productivity of a population are shifted.
\end{abstract}

Key words: small pelagic fishes, stocks, physical forcing, Baja California, habitat.

RESUMEN. Los peces pelágicos menores son importantes indicadores ecológicos del estado del Sistema de la Corriente de California, ya que su abundancia y distribución se ven alteradas directamente en respuesta a los forzamientos climáticos. Estas especies forman cardúmenes, consumen plancton y son forraje para niveles tróficos superiores. En este trabajo se describen las historias de vida y los patrones de distribución de la sardina, anchoveta y dos especies de macarela que ocupan aguas del océano Pacífico frente a la península de Baja California (México). Desde el punto de vista de las pesquerías (cuando la información está disponible), se abordan temas relacionados con los forzamientos biofísicos que mantienen y estructuran la condición del hábitat de las especies, sus patrones de movimiento, su productividad y la estructura poblacional relativo a las subpoblaciones. A pesar de que la información basada en las pesquerías puede estar sesgada por la escala de operación y las áreas de disponibilidad de los peces, en este trabajo las capturas se utilizan como indicadores de la historia de vida de las diferentes subpoblaciones. Para evaluar la validez de varios paradigmas existentes en oceanografía pesquera, se utilizaron principalmente estudios basados en sardina. Por último, con el objetivo de describir cómo el ambiente puede establecer la estructura poblacional de los peces pelágicos, se discute la variabilidad espaciotemporal de las dos subpoblaciones, norteña y sureña, de sardina (Sardinops sagax) y macarela (Scomber japonicus) de 2000 a 2014. En respuesta al enfriamiento regional mantenido desde el inicio de este periodo, las subpoblaciones norteñas muestran una tendencia a contraerse hacia el sur del sistema, hasta aguas frente a bahía Magdalena. Estos cambios en distribución y productividad de una población parecen ser resultado de los efectos combinados de la pesca y el cambio en el clima del océano que podrían alterar las características del hábitat.

Palabras clave: peces pelágicos menores, subpoblaciones, forzamientos, Baja California, hábitat.

\section{INTRODUCTION}

The aim of this paper is to explore patterns of distribution and life histories of small pelagic fishes along the west coast of the Baja California Peninsula (Mexico) in the context of regional circulation of the California Current System (CCS).

\section{INTRODUCCIÓN}

El objetivo de este artículo es examinar los patrones de distribución y las historias de vida de los peces pelágicos menores a lo largo de la costa occidental de la península de Baja California (México) en el contexto de la circulación 
We focus on the most important species within the region, namely the Pacific sardine (Sardinops sagax), northern anchovy (Engraulis mordax), Pacific mackerel (Scomber japonicus), and jack mackerel (Trachurus symmetricus). Climate variability over seasonal to interdecadal time scales acts to modify the physicochemical and biological characteristics of the habitat occupied by these species. Their mobility allows them to move their spawning grounds both in time and space and to select favorable areas for spawning to ensure reproductive success to sustain their populations. We review the historical trends of the commercial catches and the variability in the distribution of spawning and abundance of eggs as indicators of movement and productivity of the different stocks. Special interest is given to Pacific sardine and Pacific mackerel since they are subject to active management in the Baja California fisheries and show important variation in catches over the scales of months to several decades, and they have suffered historical population collapses in the 20th century.

Small pelagic fishes are key components in the CCS. They are planktivorous species that exhibit schooling behavior and multiple spawning over an annual cycle, and generally occur in large biomasses, have a wide distribution range, and thus share some life history traits. Together with euphausiids, these species represent more than $10 \%$ of the biomass of the CCS and affect the abundance, condition, and behavior of upper trophic levels in the food web (Kaplan et al. 2013). One important characteristic is their sensitivity to environmental change, which makes them vulnerable to variations in physical forcing (Parrish et al. 1981) and has resulted in dramatically fluctuating abundances (Lluch-Belda et al. 1989, Schwartzlose et al. 1999, Alheit et al. 2009). However, their commercial exploitation, which represents roughly $25 \%$ of the world's fish catch (Checkley et al. 2009), has also been responsible for historical changes in their productivity (Hsieh et al. 2006, Rykaczewski and Checkley 2008). Because they integrate the productivity of lower trophic levels, their often dramatic changes in population size make small pelagic fish important indicators of the response of the pelagic ecosystem to changes in ocean climate.

A population is vulnerable to the combination of fishing and unfavorable environmental conditions that may act to reduce their reproductive capacity (Hsieh et al. 2006, Anderson et al. 2008). Planktivorous pelagic species experience higher susceptibility to fisheries due to the removal of older fish, resulting in truncated age and size distributions as well as their high fecundities (Anderson et al. 2008). According to Peck et al. (2013), the collapse and replacement of a population begins with a change in abundance due to smaller year-class sizes linked to lower reproductive success. Since the correct evaluation of time and spatial scales of distribution and abundance may be biased due to the operational scale of fishing, independent methods are needed to evaluate the natural state of the populations. The information depends on factors such as longevity of the species and their patterns regional del Sistema de la Corriente de California (SCC). Nos enfocaremos en las especies más importantes de la región: la sardina del Pacífico (Sardinops sagax), la anchoveta (Engraulis mordax), la macarela del Pacífico (Scomber japonicus) y el charrito (Trachurus symmetricus). La variabilidad climática en diferentes escalas (estacionales a interdecadales) contribuye a modificar las características físicas, químicas y biológicas del hábitat de estas especies. Su movilidad les permite cambiar sus zonas de desove tanto en el tiempo como en el espacio, y así garantizar el éxito reproductivo para sostener sus poblaciones. Se examinan las tendencias históricas de las capturas comerciales, la variabilidad de la distribución del desove y la abundancia de huevos como indicadores del movimiento y la productividad de las diferentes subpoblaciones. Se hace énfasis en la sardina del Pacífico y la macarela del Pacífico ya que son objeto de un manejo activo en las pesquerías de Baja California y muestran una importante variación de sus capturas en escalas de meses a décadas, además de que han sufrido colapsos históricos de sus poblaciones en el siglo XX.

Los peces pelágicos menores son componentes clave en el SCC. Estas especies generalmente presentan elevadas biomasas y una amplia distribución. Además, comparten algunas características de sus ciclos de vida, entre ellas el ser planctívoras, formar cardúmenes y desovar en múltiples ocasiones duante un ciclo anual. Junto con eufáusidos, estas especies representan más del $10 \%$ de la biomasa del SCC y afectan la abundancia, la condición y el comportamiento de los niveles tróficos superiores en la cadena alimenticia (Kaplan et al. 2013). Una característica importante es su sensibilidad a cambios ambientales, lo que las hace vulnerables a las variaciones en los forzamientos físicos (Parrish et al. 1981) que conllevan a drásticas fluctuaciones en sus abundancias (Lluch-Belda et al. 1989, Schwartzlose et al. 1999, Alheit et al. 2009). Por otro lado, su explotación comercial, que representa alrededor del $25 \%$ de la captura de peces a nivel mundial (Checkley et al. 2009), también ha sido responsable de los cambios históricos en su productividad (Hsieh et al. 2006, Rykaczewski y Checkley 2008). Puesto que los peces pelágicos menores integran la productividad de niveles tróficos inferiores, los cambios en el tamaño de la población, a menudo drásticos, los convierte en indicadores importantes de la respuesta del ecosistema pelágico a los cambios del clima oceánico.

Una población es vulnerable a la combinación de la pesca y condiciones ambientales desfavorables que pueden reducir su capacidad reproductiva (Hsieh et al. 2006, Anderson et al. 2008). Las especies pelágicas planctívoras son más susceptibles a las pesquerías debido a la remoción de individuos adultos que resulta en distribuciones de edad, talla y fecundidad truncadas (Anderson et al. 2008). Según Peck et al. (2013), el colapso y reemplazo de una población comienza con un cambio en la abundancia vinculado a clases anuales menores debido a un menor éxito reproductivo. Puesto que la evaluación correcta de las escalas temporales y espaciales de 
of movement over the annual cycle, as well as interannual and decadal scale changes.

This paper addresses relevant aspects of the life history and distribution of the small pelagic species living in waters of the Baja California Peninsula. We begin with a description of the physical setting of the CCS, followed by more general aspects of how the life cycle of the species is coupled to ocean climate to determine their patterns of abundance and distributions, and we then describe the concept of stocks and demographic characteristics that distinguish each of these subpopulations. Note that we designate the different sardine stocks with names that reflect their association with the water masses in which they reside, that is, "subarctic" stock and "subtropical" stock rather than "cold" and "temperate", respectively, as used by Félix-Uraga et al. (2004). Sometimes we refer to "temperate subtropical" and "cold subarctic" stocks.

Furthermore, we explore the population dynamics of small pelagics in the waters off northern Baja California in relation to their abundance based on catch statistics provided by the National Fisheries Institute (INAPESCA) for sardine, mackerel, and anchovy (Cota-Villavicencio et al. 2010). In order to evaluate the validity and usefulness of existing paradigms in fisheries oceanography, and to stress the importance of the interaction of ocean climate with fisheries resources, we have included our own interpretations and data regarding sardine dynamics and behavior in Baja California waters. As there is much more information available for sardines than for other small pelagic species, thanks to efforts dating back to the 1930s focusing on the Pacific sardine, we use the example of sardines more frequently to illustrate many of the ideas and interpretations presented with respect to small pelagic fish.

\section{Physical SETting}

The structure and organization of a wide variety of small pelagic fish species along the CCS are closely coupled to the physics and climate dynamics of the upper $200 \mathrm{~m}$ of the water column (Mackas 2006, Baumgartner et al. 2008, Checkley and Barth 2009, Durazo 2009). The seasonal biological production of a wide variety of plankton species is stimulated by the injection of nutrient-rich cold and salty water to the upper layer by coastal upwelling throughout the year (Rykaczewski and Checkley 2008). The result of this forcing is the creation of a nearshore transition region that separates cold upwelled waters found along the coast from less dense, warmer, and less saline water offshore. The coastal area is dominated by offshore Ekman transport and the oceanic region is dominated by geostrophic flow (Lynn and Simpson 1987, Durazo and Baumgartner 2002). Newly upwelled water is usually transported to the ocean interior by cold filaments and mesoscale structures $(\sim 80-100 \mathrm{~km})$ that extend 200-400 km (Mackas 2006, Checkley and Barth 2009). In the oceanic zone ( 1000 km offshore and from the distribución y abundancia puede estar sesgada por la escala operacional de la pesca, se requieren métodos independientes para estudiar el estado natural de las poblaciones. La información depende de factores tales como la longevidad de las especies y sus patrones de movimiento durante un ciclo anual, así como cambios de escala interanual y decadal.

Este artículo aborda aspectos relevantes de la historia de vida y distribución de las especies pelágicas menores que habitan aguas frente a la península de Baja California. Se presenta una descripción del entorno físico del SCC, se analizan aspectos más generales en cuanto a cómo el ciclo de vida de las especies está ligado al clima oceánico para determinar sus patrones de abundancia y distribución, y se describe el concepto de subpoblaciones y sus características demográficas que las distinguen. Nótese que designamos las diferentes subpoblaciones de sardina con nombres que reflejan su asociación con las masas de agua en las cuales habitan, esto es, subpoblación "subártica" y subpoblación "subtropical", a diferencia de Félix-Uraga et al. (2004) quienes usaron "fría" y "templada", respectivamente. A veces usamos "templado subtropical" y "frío subártico".

Además, se analiza la dinámica poblacional de pelágicos menores en las aguas frente a la parte norte de la península de Baja California en relación a su abundancia con base en las estadísticas de captura proporcionadas por el Instituto Nacional de Pesca (INAPESCA) para sardina, macarela y anchoveta (Cota-Villavicencio et al. 2010). Para evaluar la validez y utilidad de paradigmas existentes en la oceanografía pesquera, así como recalcar la importancia de la interacción del clima océanico con los recursos pesqueros, hemos incluido nuestras interpretaciones y datos en cuanto a la dinámica y comportamiento de la sardina en aguas baja californianas. En vista de que existe mucho más información para la sardina que para otros peces pelágicos menores, gracias a estudios que remontan a los años treinta del siglo pasado, principalmente sobre la sardina del Pacífico, usamos el ejemplo de la sardina con mayor frecuencia para ilustrar varias ideas e interpretaciones en torno a estas especies.

\section{ENTORNO FÍSICO}

La estructura y organización de una gran variedad de peces pelágicos menores a lo largo del SCC se relacionan estrechamente con la física y la dinámica del clima en los primeros $200 \mathrm{~m}$ de la columna de agua (Mackas 2006, Baumgartner et al. 2008, Checkley y Barth 2009, Durazo 2009). La producción biológica estacional de varias especies planctónicas se ve favorecida por la inyección de aguas saladas, frías y ricas en nutrientes a la capa superior mediante las surgencias costeras que se presentan a lo largo del año (Rykaczewski y Checkley 2008). El resultado de este forzamiento es la creación de una zona de transición cerca de la costa que separa las aguas costeras frías de las aguas oceánicas más cálidas y menos densas y salinas. La zona costera es dominada por el transporte de Ekman hacia fuera de la 


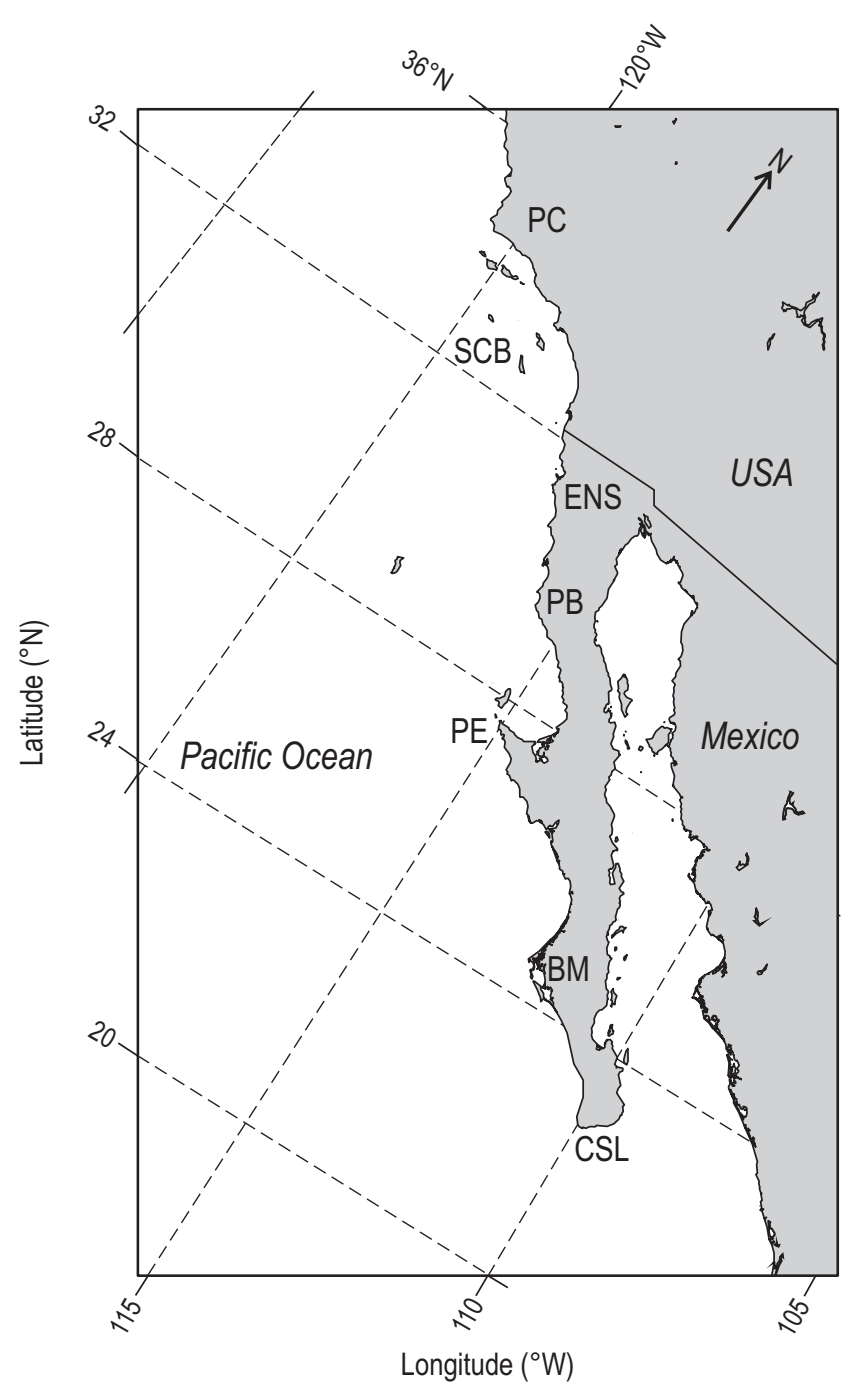

Figure 1. Map showing the location of the sites mentioned in the text: Point Conception (PC), Southern California Bight (SCB), Ensenada (ENS), Punta Baja (PB), Punta Eugenia (PE), Bahía Magadalena (BM), and Cabo San Lucas (CSL).

Figura 1. Mapa que muestra la ubicación de los sitios mencionados en el texto: punta Concepción (PC), cuenca del Sur de California (SCB), Ensenada (ENS), punta Baja (PB), punta Eugenia (PE), bahía Magdalena (BM) y cabo San Lucas (CSL).

surface to $300 \mathrm{~m}$ ), the equatorward flow of the California Current (CC) carries cold, low-salinity water to subtropical and tropical latitudes (Lynn and Simpson 1987).

Along the coast, there are regions where coastal upwelling produced by the alongshore winds may be enhanced by wind stress divergence and topographic effects. Wind stress curl promotes upwelling outside the influence of the continental border (Landry et al. 2012). Positive curl within the Southern California Bight is associated with the presence of a cyclonic gyre. The southern edge of this large eddy is known as the Ensenada front centered around $31^{\circ} \mathrm{N}$. This gyre separates the north-central California region from the Southern costa y la región oceánica es dominada por el flujo geostrófico (Lynn y Simpson 1987, Durazo y Baumgartner 2002). El agua recién surgida es normalmente transportada mar adentro por filamentos fríos y estructuras de mesoescala $(\sim 80-100 \mathrm{~km})$ que se extienden 200-400 km (Mackas 2006, Checkley y Barth 2009). En la zona oceánica $(\sim 1000 \mathrm{~km}$ de la costa y desde la superficie hasta $300 \mathrm{~m}$ de profundidad), el flujo hacia el ecuador de la corriente de California (CC) acarrea agua fría y de baja salinidad a latitudes subtropicales y tropicales (Lynn y Simpson 1987).

En la costa, hay regiones donde se intensifica la surgencia costera inducida por el viento debido a la divergencia del esfuerzo del viento y efectos topográficos. El rotor del esfuerzo del viento induce surgencias afuera de la influencia del borde continental (Landry et al. 2012). Un rotor positivo dentro de la cuenca del Sur de California se asocia con la presencia de un giro ciclónico. El borde sur de este gran remolino se conoce como el Frente de Ensenada (centrado $31^{\circ} \mathrm{N}$ ). El giro separa la región norcentral de California de la cuenca del Sur de California y las aguas baja californianas en punta Concepción $\left(34^{\circ} \mathrm{N}\right)$ (fig. 1). A causa de este frente, el agua oceánica oligotrófica se transporta hacia la costa, lo cual suprime la producción primaria hacia el sur y conduce a concentraciones relativamente bajas de clorofila en la zona costera frente a Ensenada (Baumgartner et al. 2008). La elevación de la termoclina que sucede alrededor de cabos debido a efectos topográficos se observa en punta Baja $\left(30^{\circ} \mathrm{N}\right)$ y punta Eugenia $\left(28^{\circ} \mathrm{N}\right)$. Aquí, la surgencia se intensifica debido a la interacción del flujo promedio de la CC con ambos cabos (Barth et al. 2000). Esta región muestra un rotor del esfuerzo del viento negativo, a diferencia de los valores positivos hacia el norte y el sur (Nelson 1977), lo que implica una circulación en dirección de las manecillas del reloj. No obstante, la presencia de una circulación ciclónica casi permanente y aguas relativamente frías durante todo el año (Lynn y Simpson 1987, Durazo 2015) sugiere que la surgencia en el área es dominada más por la interacción entre la corriente y los cabos que por el rotor del esfuerzo del viento. La presencia de surgencias intensificadas debido a los cabos proporciona las condiciones necesarias para un buen suministro de nutrientes, mientras que la presencia de una circulación ciclónica proporciona el mecanismo físico para el crecimiento y la supervivencia de larvas. Un rotor del esfuerzo del viento positivo también podría ser importante en el golfo de Ulloa $\left(\sim 26^{\circ} \mathrm{N}\right)$, donde existen condiciones adecuadas para una productividad alta debido a la combinación del suministro de agua rica en nutrientes de punta Eugenia, la circulación ciclónica asociada con la divergencia del viento y la contribución de aguas del sur por el transporte inducido por un flujo costero hacia el polo de verano a invierno. Por lo tanto, la variabilidad espacial y temporal del rotor del esfuerzo del viento a lo largo de la península (Durazo 2015) puede jugar un papel importante en el bombeo estacional de nutrientes a la zona eufótica, así como estructurar los gradientes costa-océano de los productores primarios y secundarios 
California Bight and the waters off Baja California at Point Conception $\left(34^{\circ} \mathrm{N}\right)$ (fig. 1). The front causes more oligotrophic ocean water to be entrained towards the coast, which suppresses primary production to the south, resulting in relatively low concentrations of chlorophyll in the coastal area off Ensenada (Baumgartner et al. 2008). Elevation of the thermocline observed around capes because of topographic effects occurs at Punta Baja $\left(30^{\circ} \mathrm{N}\right)$ and Punta Eugenia $\left(28^{\circ} \mathrm{N}\right)$. Here, enhanced upwelling is produced by the interaction of the mean flow of the CC with both capes (Barth et al. 2000). This region exhibits negative wind stress curl, different from the positive values north and south (Nelson 1977), which would imply clockwise circulation. However, the presence of a quasi-permanent cyclonic circulation and relatively cold waters year-round (Lynn and Simpson 1987, Durazo 2015) suggests that localized upwelling is dominated by the current-cape interaction rather than wind stress curl. Capeenhanced upwelling upstream provides the necessary conditions for high nutrient supply, while the presence of cyclonic circulation provides the physical mechanism for larval growth and survival. Positive wind stress curl may also be important in the Gulf of Ulloa $\left(\sim 26^{\circ} \mathrm{N}\right)$, where the combination of upstream nutrient-rich water supply from Punta Eugenia, the cyclonic circulation associated with wind divergence, and the contribution of southern waters by the transport induced by a poleward coastal flow from summer to winter, secures the required conditions for high productivity. Thus, the spatial and temporal variability of wind stress curl along the peninsula (Durazo 2015) may play a key role in the seasonal pumping of nutrients to the euphotic zone, and may also structure the onshore-offshore gradients of primary and secondary producers off Baja California, as has been suggested by Rykaczewsky and Checkley (2008).

We use the hypothesis of Logerwell and Smith (2001) to examine the paradigm that "environmentally based recruitment models, when updated with new data, invariably fail" (Leggett and Frank 2008). Logerwell and Smith (2001) propose that eddies could provide a mechanism for offshore expansion of favorable habitat for growth and survival of sardine larvae with a higher concentration of chlorophyll within the eddies. Cyclonic and anticyclonic eddies propagate to the west at $\sim 2 \mathrm{~km}$ per day (Kurian et al. 2011). However, despite providing a mechanism for offshore expansion of favorable habitat for early life stages of sardines, Nieto et al. (2014) provide evidence that the offshore advection reduces recruitment success due to the ultimate loss of the reproductive products from the population. Nonetheless, it is reasonable that eddies located near or inshore of the axis of the CC (see fig. 5 in Nieto et al. 2014) would allow larvae and early juveniles to reach the nearshore nurseries and survive to recruit to the adult population. This study by Nieto et al. (2014) contradicts the hypothesis proposed by Logerwell and Smith (2001) and can be used as the basis of an improved hypothesis since their results indicate increased recruitment during warm El Niño years and poor recruitment during cool La Niña years, frente a Baja California, como ha sido sugerido por Rykaczewsky y Checkley (2008).

Se usó la hipótesis de Logerwell y Smith (2001) para examinar el paradigma de que "los modelos de reclutamiento basados en el medio ambiente invariablemente fallan al ser actualizados con datos nuevos" (Leggett y Frank 2008). Logerwell y Smith (2001) proponen que los remolinos podrían proporcionar un mecanismo para la expansión mar adentro de un hábitat favorable para el crecimiento y la supervivencia de larvas de sardina con una mayor concentración de clorofila dentro de ellos. Típicamente, los remolinos ciclónicos y anticiclónicos se propagan hacia el oeste a una velocidad de $\sim 2 \mathrm{~km}$ por día (Kurian et al. 2011). Sin embargo, a pesar de proporcionar un mecanismo para la expansión mar adentro de un hábitat favorable para las etapas tempranas de sardinas, Nieto et al. (2014) proporcionan evidencia de que la advección mar adentro reduce el éxito del reclutamiento debido a la pérdida de los productos reproductivos de la población. No obstante, es razonable suponer que los remolinos localizados dentro del eje de la CC (ver fig. 5 de Nieto et al. 2014) permitan a larvas y juveniles tempranos alcanzar sitios de crianza y favorecer la supervivencia para que se recluten a la población adulta. Este estudio de Nieto et al. (2014) contradice la hipótesis de Logerwell y Smith (2001) y puede ser usado como la base de una hipótesis mejorada ya que sus resultados indican que el reclutamiento aumenta durante años cálidos de El Niño y es pobre durante años fríos de La Niña, lo que sugiere que el transporte de remolinos aumenta debido a la dinámica de Ekman. Las condiciones de El Niño, mientras tanto, impiden el transporte mar adentro de larvas y juveniles y posiblemente mejoren la supervivencia por el transporte hacia la costa o simplemente por retener una densidad relativamente alta de alimento en la zona costera.

Las escalas espaciales a nivel de cuenca también regulan las características del hábitat del SCC. Los cambios principalmente se asocian con la circulación atmosférica a gran escala que genera cambios importantes en el ambiente oceánico. En el Pacífico nororiental, el campo de viento está determinado por dos centros de presión atmosférica: el centro de baja presión de las islas Aleutianas (Baja Aleutiana), ubicado aproximadamente en $50^{\circ} \mathrm{N}, 170^{\circ} \mathrm{W}$, y el centro de alta presión del Pacífico central. Esta combinación se conoce como la Oscilación del Pacífico Norte (OPN, Mackas 2006) centrado al norte de Hawái. Una intensificación de la Baja Aleutiana en invierno genera corrientes y vientos fuertes hacia el polo. La OPN se intensifica en primavera y verano y es responsable de los vientos del noroeste y la intensificación del transporte de Ekman hacia fuera de la costa frente a California y Baja California (Checkley y Barth 2009). En otoño e invierno, un debilitamiento del sistema de alta presión resulta en una disminución del flujo hacia el ecuador (U.S. GLOBEC 1994). Los cambios interanuales a decadales en la posición y magnitud de la OPN modifican los vientos favorables para surgencias, la temperatura superficial 
suggesting that transport of eddies is increased by Ekman dynamics. El Niño conditions impede offshore transport of larvae and early juveniles and may even improve survival by onshore transport or by simply retaining a relatively high density of food in the coastal zone.

Basin-wide scales also modulate the habitat characteristics of the CCS. The changes are mainly associated with the large-scale atmospheric circulation which results in important changes in the oceanic environment. In the eastern North Pacific, the wind field is controlled by two atmospheric pressure centers: the Aleutian low-pressure system, located at approximately $50^{\circ} \mathrm{N}, 170^{\circ} \mathrm{W}$, and the central Pacific highpressure center. This combination is known as the North Pacific Oscillation (NPO, Mackas 2006) centered north of Hawaii. An enhanced Aleutian Low during winter creates strong poleward winds and currents. The NPO intensifies in the spring and summer and is responsible for the northwesterly winds and intensification of the offshore Ekman transport off central California and Baja California (Checkley and Barth 2009). In autumn and winter, the weakening of the high pressure system causes a reduction in the equatorward flow (U.S. GLOBEC 1994). Interannual to decadal changes in the position and magnitude of the NPO modify upwellingfavorable winds, sea surface temperature (SST), and sea level at those scales. Over the oceanic environment, the changes are seen as variations in the relative contributions of the major water masses in the upper $300 \mathrm{~m}$, namely the equatorward flow of subarctic water and the poleward transport of tropical and subtropical waters.

The Pacific Decadal Oscillation (PDO, Mantua et al. 1997) and the North Pacific Gyre Oscillation (NPGO, Di Lorenzo et al. 2008) are the main modes of variability in the North Pacific Ocean forced by the pressure centers. Fluctuations in these modes have been associated with variations in salinity, nutrients, and chlorophyll, with consequences at all trophic levels (Durazo 2009, Lavaniegos 2009). Di Lorenzo et al. (2013) have suggested that the Aleutian Low controls the PDO and that it is associated with the first mode of SST anomalies obtained for the entire North Pacific. The warm phase of the PDO is associated with the deepening of the Aleutian Low and a weakening in the equatorward flow of the CC (King et al. 2011). The response to weakened upwelling-favorable winds is the anomalous increase of nearshore sea level and SST that relaxes the ocean pressure gradient towards the coast. The NPGO is the oceanic response to the NPO forcing, identified as the second mode in the sea level anomaly for the central and eastern North Pacific $\left(180-110^{\circ} \mathrm{W}, 25-62^{\circ} \mathrm{N}\right.$; Di Lorenzo et al. 2010). The positive phase of the NPGO is associated with the intensification of the NPO, which in turn intensifies northwesterly winds and strengthens the equatorward flow of the $\mathrm{CC}$.

El Niño Southern Oscillation (ENSO) is another ocean-atmosphere phenomenon that influences ocean habitat. There are two types of ENSO, the canonical El Niño and del mar (TSM) y el nivel del mar a esas escalas. En el ambiente oceánico, los cambios se perciben como variaciones en las contribuciones relativas de las principales masas de agua en los primeros $300 \mathrm{~m}$, es decir, el flujo hacia el ecuador de agua subártica y el transporte hacia el polo de aguas tropicales y subtropicales.

La Oscilación Decadal del Pacífico (ODP, Mantua et al. 1997) y la Oscilación del Giro del Pacífico Norte (OGPN, Di Lorenzo et al. 2008) son los principales modos de variabilidad en el Pacífico Norte forzados por los centros de presión atmosférica. Las fluctuaciones en estos modos se han asociado con variaciones en salinidad, nutrientes y clorofila, con consecuencias en todos los niveles tróficos (Durazo 2009, Lavaniegos 2009). Di Lorenzo et al. (2013) sugirieron que la Baja Aleutiana controla la ODP y que está asociada con el primer modo de las anomalías de la TSM del Pacífico Norte. La fase cálida de la ODP se asocia con la intensificación de la Baja Aleutiana y un debilitamiento del flujo hacia el ecuador de la CC (King et al. 2011). La respuesta a un debilitamiento de los vientos favorablas para surgencias es un aumento anómalo de la TSM y el nivel del mar cerca de la costa que reduce el gradiente de presión oceánico hacia la costa. La OGPN es la respuesta oceánica al forzamiento de la OPN, que se identifica como el segundo modo de la anomalía del nivel del mar para el Pacífico Norte central y oriental $\left(180-110^{\circ} \mathrm{W}, 25-62^{\circ} \mathrm{N}\right.$; Di Lorenzo et al. 2010). La fase positiva de la OGPN se asocia con la intensificación de la OPN, que a su vez intensifica los vientos del noroeste y el flujo hacia el ecuador de la CC.

Otro proceso oceáno-atmósfera que afecta el hábitat oceánico es El Niño/Oscilación del Sur (ENOS). Existen dos tipos de ENOS: El Niño canónico y El Niño que se presenta en el Pacífico central (Kug et al. 2009). Di Lorenzo et al. (2013) propusieron un modelo conceptual en el que la variabilidad del clima en el Pacífico Norte durante varias décadas produce una redistribución hacia el polo del calor proveniente de latitudes tropicales. El calentamiento provocado por ENOS en regiones ecuatoriales modifica la circulación atmosférica zonal y meridional (células de Hadley y Walker), lo cual eventualmente altera los patrones globales de precipitación y evaporación. La redistribución del calor tropical relacionado con cambios en las masas de agua y los campos de estrés del viento (Durazo y Baumgartner 2002) puede tener un efecto de abajo hacia arriba en la cadena alimenticia del ecosistema (U.S. GLOBEC 1994, Checkley y Barth 2009, McFarlane et al. 2010).

\section{ADAPTACIÓN DEL CICLO DE VIDA A LA VARIABILIDAD DE LAS CONDICIONES OCEÁNICAS}

Las historias de vida de los peces pelágicos menores muestran adaptaciones similares que les permiten acoplarse a las variaciones estacionales de las condiciones del hábitat pelágico, las cuales incluyen la búsqueda de alimento, la reproducción y el crecimiento (Blaxter y Hunter 1982). Para 
El Niño occurring in the central Pacific (Kug et al. 2009). Di Lorenzo et al. (2013) proposed a conceptual model in which climate variability in the North Pacific over several decades produces a poleward redistribution of heat from tropical latitudes. The warming in the equatorial regions caused by ENSO modifies the zonal and meridional atmospheric circulation (Hadley and Walker cells), which eventually alters rainfall and evaporation global patterns. A redistribution of tropical heat associated with changes in water masses and wind stress fields (Durazo and Baumgartner 2002) may cause a bottom-up effect in the food web of the ecosystem (U.S. GLOBEC 1994, Checkley and Barth 2009, McFarlane et al. 2010).

\section{LIFE CYCLE ADJUSTMENTS TO VARIABILITY IN OCEAN CONDITIONS}

Small pelagic fish have similar adaptations of their life histories that allow them to adjust to seasonal variability in the conditions of the pelagic habitat including the search of food, reproduction, and growth (Blaxter and Hunter 1982). Their migration patterns and schooling behavior used for foraging and protection against predators are perhaps the most important features that allow them to accomplish this (Radovich 1982, PFMC 1998). Relatively large sizes of individuals are found in both Pacific mackerel and jack mackerel, which are presumably adapted to a greater range of movement in their foraging. Their reproduction is oviparous at night, with multiple spawning over the year so that their peak spawning is apparently linked to peaks in food availability (Blaxter and Hunter 1982).

With the exception of $T$. symmetricus, all small pelagic species belong to intermediate trophic levels (2-3). However, significant seasonal changes in wind stress modify both the habitat characteristic and the composition of food on which small pelagics depend (table 1). In particular, anchovies can act as filter or particulate feeders. In the latter case, which is the dominant, they have the ability to select copepods and euphausiids (Van der Lingen et al. 2009). Although it is not mentioned by Van der Lingen et al. (2009), we believe that only juvenile anchovies would select copepods, since the size of the prey determines the size of the predator. Trachurus symmetricus is the species with the greatest longevity (>30 years), highest fecundity $\left(1.85 \times 10^{6}\right.$ eggs year $\left.^{-1}\right)$, and greatest size $(\sim 80 \mathrm{~cm})$ of the small pelagics. It feeds on crustaceans, small fish, and pelagic mollusks (Demer et al. 2012). Sardines have a finer branchial basket with more gill rakers and very fine teeth that are likely to improve harvesting of their predominant supply of food in their habitat (Van der Lingen et al. 2009). Because sardines posses a special organ that allows them to process vegetative matter, they are able to feed on both phytoplankton as well as crustaceans (McFarlane et al. 2005, 2010). Their larvae show a preference for copepods with average sizes of $\sim 3 \mathrm{~mm}$ (Van der Lingen et al. 2009). The Pacific mackerel is more prey- buscar alimento y protegerse de los depredadores, estas especies poseen patrones de migración y un comportamiento agregativo (forman cardúmenes) (Radovich 1982, PFMC 1998). Tanto S. japonicus como T. symmetricus tienen individuos de tamaño relativamente grande, los cuales presuntamente están adaptados para tener mayor rango de movimiento para buscar alimento. Todas las especies tienen reproducción ovípara, nocturna, y desovan en múltiples ocasiones durante un año, por lo que la máxima actividad de desove aparentemente está relacionada con una mayor disponibilidad de alimento (Blaxter y Hunter 1982).

Con excepción de T. symmetricus, todas las especies de peces pelágicos menores pertenecen a niveles tróficos intermedios (2-3); sin embargo, cambios estacionales importantes en el esfuerzo del viento modifican tanto la característica del hábitat como la composición del alimento de que dependen los pelágicos menores (tabla 1). En particular, las anchovetas se alimentan por filtración o por depredación del zooplancton (alimentación por partículas). En el segundo caso, que es el dominante, tienen la capacidad de seleccionar copépodos y eufáusidos (Van der Lingen et al. 2009). Aunque no lo mencionan Van der Lingen et al. (2009), nosotros consideramos que sólo los individuos juveniles seleccionarían copépodos ya que el tamaño de la presa determina el tamaño del depredador. Entre los pelágicos menores, T. symmetricus es la especie más longeva ( $>30$ años), de mayor fecundidad $\left(1.85 \times 10^{6}\right.$ huevos año $\left.{ }^{-1}\right)$ y de mayor tamaño $(\sim 80 \mathrm{~cm})$. Se alimenta de crustáceos, peces pequeños y moluscos pelágicos (Demer et al. 2012). Las sardinas tienen una red branquial con mayor número de branquiespinas y dientes muy finos que probablemente mejoren la recolección de su principal fuente de alimento (Van der Lingen et al. 2009). Debido a que las sardinas presentan un órgano especial que les permite procesar materia vegetal, son capaces de alimentarse tanto de fitoplancton como de crustáceos (McFarlane et al. 2005, 2010). Las larvas muestran una preferencia por copépodos de $\sim 3 \mathrm{~mm}$ (Van der Lingen et al. 2009). La macarela del Pacífico es más selectiva en su preferencia de presas y su dieta incluye calamar y otros moluscos pelágicos, así como peces menores como la anchoveta (CalCOFI 1953, Lo et al. 2010a, Demer et al. 2012; ver tabla 1 para una comparación de las especies).

El uso que hacen las especies de sus ambientes seleccionados en diferentes etapas de sus vidas (larvas, juveniles, adultos) es considerado una adaptación a la variabilidad estacional. El ciclo de vida de la anchoveta se asocia con zonas de surgencia costera. Presenta máxima actividad reproductiva en invierno (Checkley et al. 2009) y sus áreas de desove se presentan en aguas costeras y pueden extenderse hasta $\sim 300 \mathrm{~km}$ mar adentro (Blaxter y Hunter 1982). En comparación con otras especies de pelágicos menores, el charrito generalmente se asocia con ambientes oceánicos oligotróficos (PFMC 1998, Anderson et al. 2008, Demer et al. 2012) y presenta máxima actividad reproductiva en junio (Macewicz y Hunter 1993). Su centro de abundancia se 
Ciencias Marinas, Vol. 41, No. 4, 2015

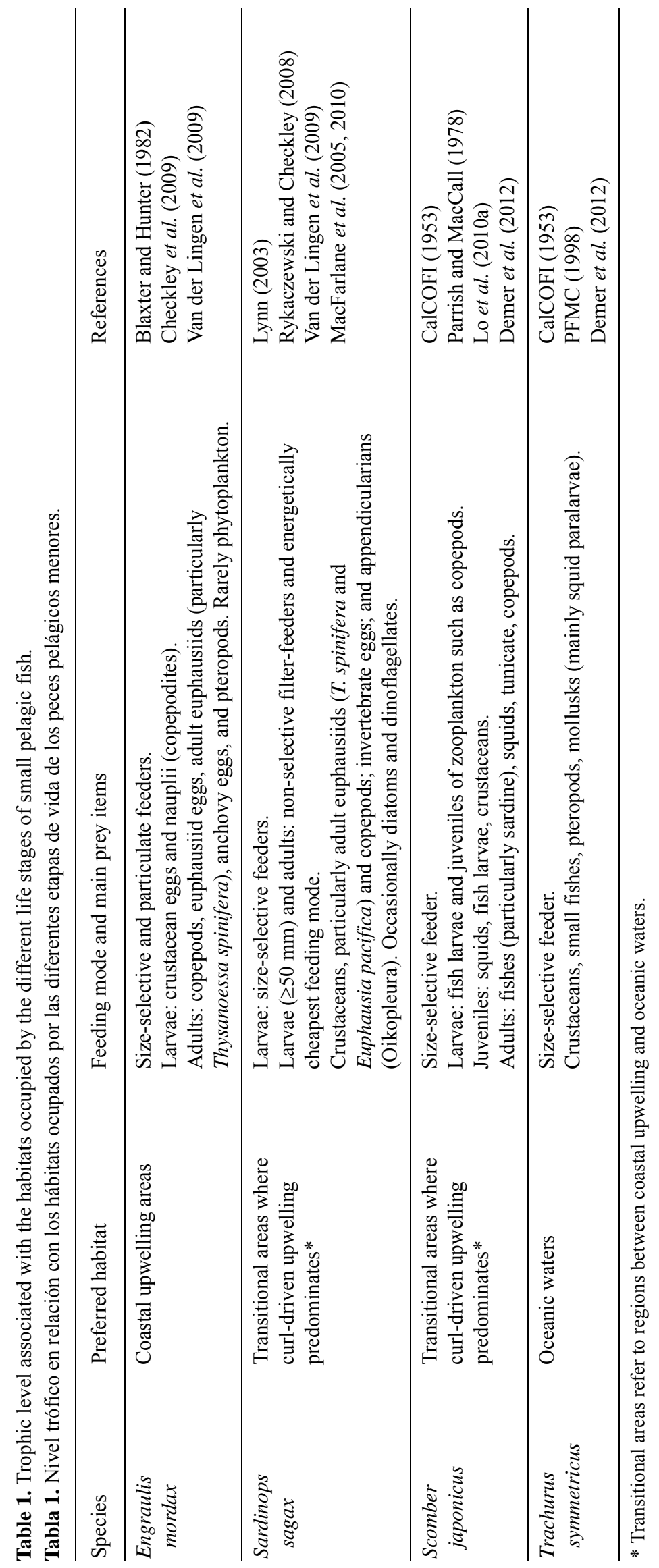


selective and its diet includes squid and other pelagic mollusks as well as smaller fish such as anchovy (CalCOFI 1953, Lo et al. 2010a, Demer et al. 2012; see table 1 for comparison of the species).

The use that different species make of selected environments at different life stages (larvae, juveniles, adults) is considered an adaptation to the seasonal variability. The life cycle of anchovy is associated with upwelling coastal areas, mainly with reproductive peaks in winter (Checkley et al. 2009), and their spawning areas may extend from coastal waters to $\sim 300 \mathrm{~km}$ offshore (Blaxter and Hunter 1982). The jack mackerel is usually associated with oligotrophic oceanic environments compared to other small pelagic species (PFMC 1998, Anderson et al. 2008, Demer et al. 2012), and has a reproductive peak in June (Macewicz and Hunter 1993). Its center of abundance occurs between 150 and $400 \mathrm{~km}$ off the coast (Ahlstrom and Ball 1954). Sardine and Pacific mackerel occupy a transitional zone between the region of coastal upwelling and oceanic waters during spring, with sardine located principally off central California and mackerel off the central region of the Baja California Peninsula (Parrish and MacCall 1978, Nevárez-Martínez et al. 2006, Lo et al. 2010b). Sardine spawning peaks are in spring and summer while Pacific mackerel spawn in spring (April-May), with relatively large egg size in the north and an equatorward size gradient. In contrast to sardines, Pacific mackerel spawning exhibits extremely patchy and dense distributions (Parrish and MacCall 1978, Lo et al. 2010a; see table 2 for comparison of the species).

A reproductive strategy that allows adaptation to the habitat that a particular species occupies is the buoyancy of their eggs, which allows them to remain in the upper $90 \mathrm{~m}$ of the water column during their 1.5-4 days hatching time (Ahlstrom 1954). Additionally, the size and shape of eggs are useful characteristics for species identification. The oval eggs of anchovy are thought to be the reason for reducing cannibalism on their eggs (Blaxter and Hunter 1982). According to Moser (1996), sardines have larger and relatively buoyant spherical eggs $(1.3-2.1 \mathrm{~mm})$ compared to jack mackerel $(0.9-1.1 \mathrm{~mm})$ and Pacific mackerel $(0.8-1.3 \mathrm{~mm})$. Seasonal differences in the volume of the egg yolk sac, consisting of proteins, are also important. Vitelline dry weight of winter-spring spawned eggs represents $\sim 38 \%$ of the weight, compared to $12-25 \%$ of summer eggs (fig. 8 in Blaxter and Hunter 1982). This allows for an extended period of larval survival under starving conditions after occlusion.

Advection of larvae away from regions of low concentrations of food and/or other unfavorable factors improve their odds for survival. Dispersion due to winds and currents may also reduce the chances for survival although their specific attributes such as shape and composition, plus their short incubation period ( $<5$ days) minimize their dispersion from their area of spawning. The selection of spawning area may be an adaptive mechanism to counter or use the variability in environmental conditions, particularly at the longer decadal observa entre 150 y $400 \mathrm{~km}$ de la costa (Ahlstrom y Ball 1954). La macarela y sardina del Pacífico ocupan una zona transicional entre la región de surgencia costera y aguas oceánicas durante la primavera. La sardina principalmente se localiza frente a la parte central de California y la macarela frente a la región central de la península de Baja California (Parrish y MacCall 1978, Nevárez-Martínez et al. 2006, Lo et al. 2010b). La sardina presenta máxima actividad reproductiva en primavera y verano, mientras que la macarela solamente en primavera (abril a mayo), con huevos relativamente grandes en el norte y una reducción en el tamaño hacia el ecuador. A diferencia de la sardina, la distribución del desove de la macarela del Pacífico ocurre en parches de muy alta abundancia (Parrish y MacCall 1978, Lo et al. 2010a; ver tabla 2 para una comparación de las especies).

Una estrategia reproductiva que permite la adaptación de una especie al hábitat que ocupa es la flotabilidad de los huevos, ya que éstos pueden permanecer en los primeros $90 \mathrm{~m}$ de la columna de agua durante el tiempo de eclosión de 1.5-4 días (Ahlstrom 1954). El tamaño y la forma de los huevos son características útiles para la identificación de las especies. Se piensa que los huevos de la anchoveta tienen una forma ovalada para reducir el canibalismo (Blaxter y Hunter 1982). Según Moser (1996), los huevos de la sardina son esféricos, relativamente boyantes y de mayor tamaño $(1.3-2.1 \mathrm{~mm})$ que los del charrito $(0.9-1.1 \mathrm{~mm})$ y la macarela del Pacífico $(0.8-1.3 \mathrm{~mm})$. También son importantes las diferencias estacionales en cuanto al volumen del saco vitelino, consistente de proteínas. El peso seco del vitelo de los huevos desovados de invierno y primavera representa $\sim 38 \%$ del peso, en comparación con $12-25 \%$ de los de verano (fig. 8 de Blaxter y Hunter 1982). Esto ofrece un periodo de tiempo prolongado para la supervivencia de larvas en condiciones de inanición después de la oclusión.

La advección de larvas de zonas con concentraciones bajas de alimento y/o otros factores desfavorables mejoran sus probabilidades de supervivencia. Su dispersión debido a vientos y corrientes también puede reducir la posibilidad de supervivencia, aunque sus atribuciones específicias (e.g., forma y composición) y el relativamente corto periodo de incubación $(<5$ días $)$ minimizan su dispersión fuera del área de desove. Conforme una especie extiende su distribución espacial, la selección del área de desove podría ser un mecanismo adaptativo para contrarrestar o usar la variabilidad de las condiciones ambientales, particularmente a escalas más largas como la decadal (Ahlstrom 1960). La colonización de áreas nuevas le permite a una población establecerse en condiciones ambientales más favorables, lo cual es muy evidente en la expansión y contracción de las poblaciones de peces pelágicos menores. Esto es consistente con la asociación entre el hábitat potencial de desove y las condiciones ambientales favorables indicada por Checkley et al. (2000), Lynn (2003) y Van der Lingen et al. (2005). También existe una tendencia hacia diferencias fenotípicas en pelágicos menores 


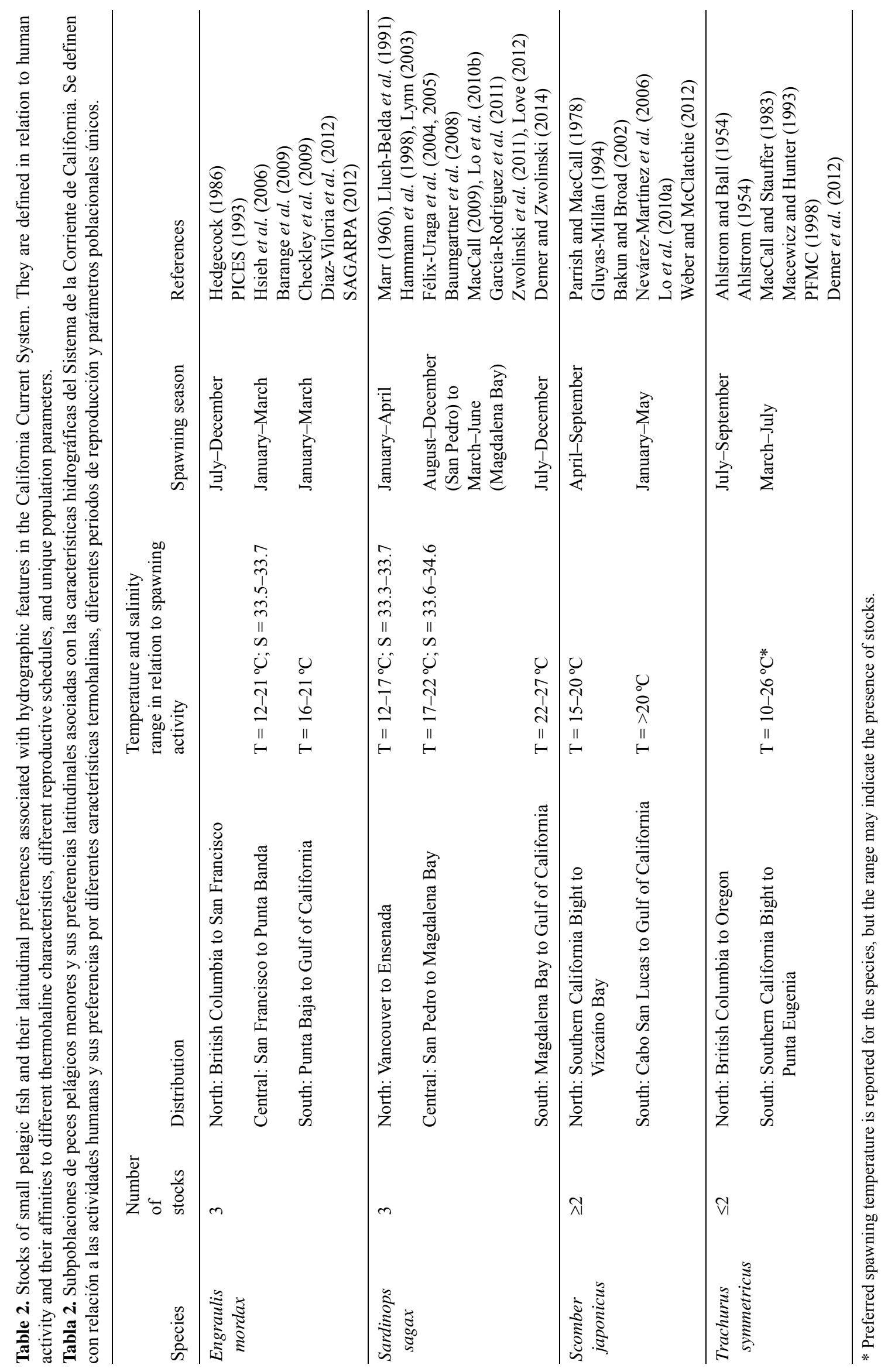




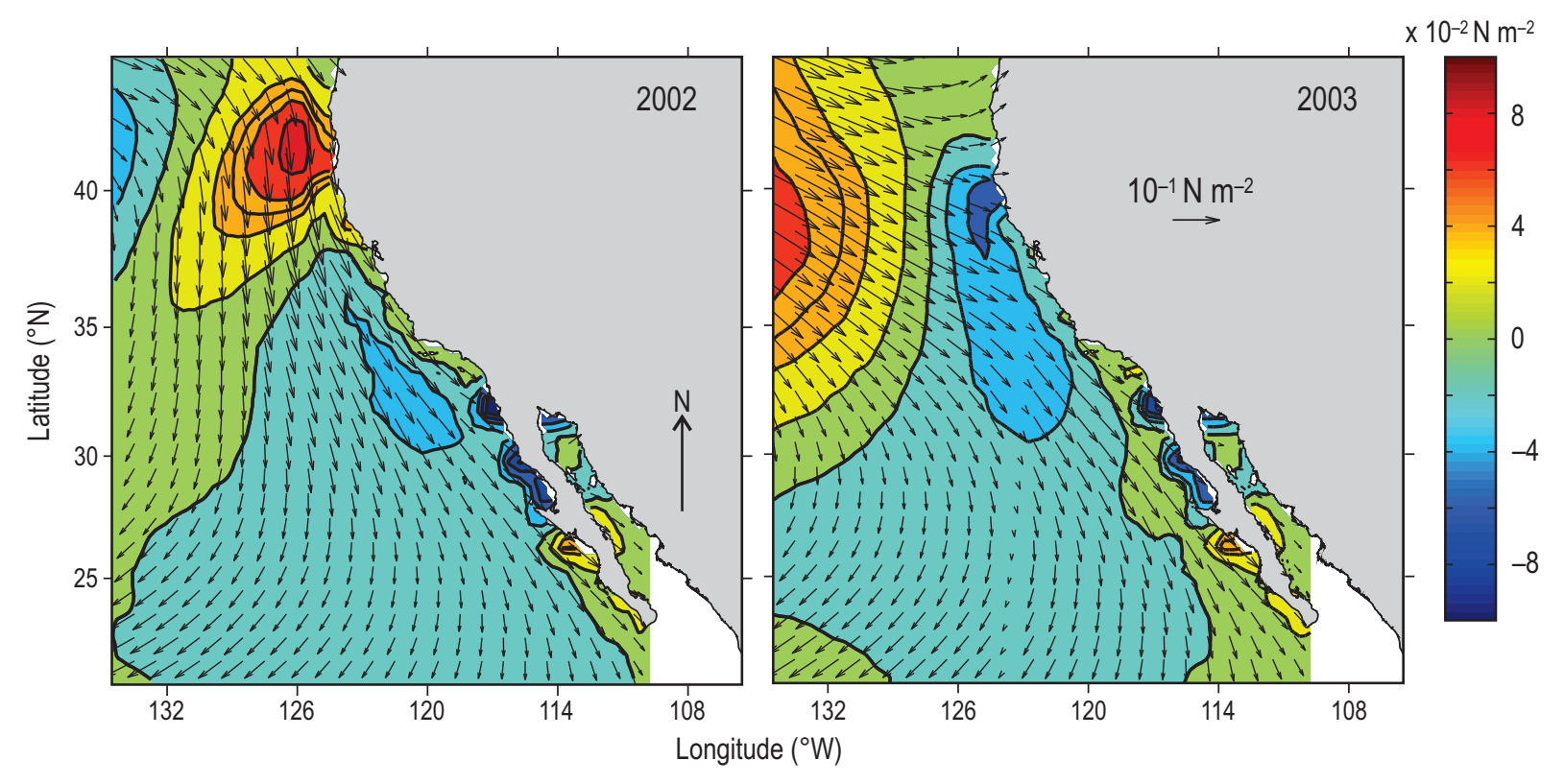

Figure 2. Sea surface wind stress (arrows) circulation patterns during April 2002 and April 2003 as derived by the SODA-POP numerical model. Color contours indicate the corresponding wind stress magnitude anomalies referred to the 1958-2008 wind stress climatology. In 2003, the figure shows a weakening of wind stress $\left(0.04 \mathrm{~N} \mathrm{~m}^{-2}\right)$ off central California, the main region where sardine spawning occurred. Contour interval is $0.02 \mathrm{~N} \mathrm{~m}^{-2}$.

Figura 2. Patrones de circulación del esfuerzo del viento en la superficie del mar (flechas) en abril de 2002 y abril de 2003 obtenidos del modelo numérico SODA-POP. Los contornos de color indican las anomalías de magnitud del esfuerzo del viento en referencia a la climatología del esfuerzo del viento de 1958 a 2008. En 2003, la figura muestra un debilitamiento del esfuerzo del viento $\left(0.04 \mathrm{~N}^{-2}\right)$ frente a la parte central de California, la región donde ocurre principalmente el desove de sardina. El intervalo de contorno es de $0.02 \mathrm{~N} \mathrm{~m}^{-2}$.

scale (Ahlstrom 1960), as a species expands its range of distribution. The colonization of new areas allows a population to establish itself under more favorable environmental conditions, which is clearly evident in the expansion and contraction of populations of small pelagic species. This is consistent with the association of potential spawning habitat with favorable environmental condition indicated by Checkley et al. (2000), Lynn (2003), and Van der Lingen et al. (2005). There is also a tendency for phenotypic differences in small pelagics in response to environmental variability, while there is little to no genetic differentiation (Smith 2005).

The physicochemical characteristics of the habitat occupied by small pelagics are mainly controlled by the structure and intensity of the wind field, which modifies the width of the coastal zone and the position of the upwelling front. These conditions may be illustrated by contrasting the conditions observed during 2002 and 2003 in the CCS (fig. 2). We used climate scenarios obtained with the data-assimilation SODA-POP numerical model developed by Carton et al. (2005), which was accessed on the Texas A\&M University website (http://sodaserver.tamu.edu). Nearshore positive (negative) salinity (temperature) anomalies were observed in 2002, consistent with an increased alongshore wind stress during La Niña. This in turn produced increased offshore Ekman transport with lifting of shelf-break subsurface water that caused salinities to rise and temperatures to fall at the en respuesta a la variabilidad ambiental, mientras que hay poca o nula diferenciación genética (Smith 2005).

Las características fisicoquímicas del hábitat ocupado por pelágicos menores están controladas principalmente por la estructura e intensidad del campo de viento, el cual modifica la anchura de la zona oceánica costera y la posición del frente de surgencia. Estas condiciones pueden ser ilustradas mediante una comparación de las condiciones observadas durante 2002 y 2003 en el SCC (fig. 2), las cuales utilizan escenarios climáticos obtenidos con el modelo numérico de asimilación de datos SODA-POP desarrollado por Carton et al. (2005), disponible en el sitio web de la Universidad de Texas A\&M (http://sodaserver.tamu.edu). En 2002 se observaron anomalías positivas (negativas) de salinidad (temperatura) cerca de la costa. Esto es consistente con un incremento del esfuerzo del viento a lo largo de la costa durante un evento de La Niña, que a su vez incrementó el transporte de Ekman hacia fuera de la costa, con la consiguiente elevación de agua subsuperficial proveniente del borde de la plataforma continental que causó un incremento de la salinidad y un decremento de la temperatura en la superficie cerca de la costa. En contraste, en 2003 los vientos se debilitaron y produjeron anomalías positivas de temperatura, el debilitamiento del gradiente de altura dinámica costa-océano, surgencias más débiles y menores salinidades. Las condiciones observadas en 2003 se relacionaron con una reducción del transporte 
surface near the coast. In contrast, winds during 2003 weakened and produced positive temperature anomalies, the relaxation of the coastal sea surface height gradient, and weaker upwelling leading to lower salinities. Conditions observed in 2003 were related to a reduced transport of CC water coincident with a decreased wind stress curl and weak vertical Ekman pumping (Durazo 2009, Durazo et al. 2010), and remained until 2006.

Since the early 1990s, the main spawning center for sardines has been located off central California, with latitudinal and onshore-offshore shifts associated with the El Niño and La Niña phenomena (Lynn 2003, Song et al. 2012). During La Niña conditions and a more intense CC in spring 2002, Baumgartner et al. (2008) showed a significant offshore movement of the subarctic stock that lives in the low salinity and cooler subarctic waters. Its spawning ground extended as far south as Punta Eugenia $\left(28^{\circ} \mathrm{N}\right)$, a behavior not previously reflected in the conceptual model of Félix-Uraga et al. (2004). In contrast, a weaker CC and a reduced offshore Ekman transport during El Niño 2003 displaced the species towards northern Baja California and central California, and compressed the stock towards the coast resulting in strong recruitment in 2004 in California and the Pacific Northwest (Lo et al. 2010b, Zwolinski and Demer 2013). In 2003, the stability of the water column would likely have been more favorable for the reproductive success of the southern subtropical stock.

Biogeographical changes in relation to the habitat are linked to the concentration and density of plankton during larval and adult stages, producing an increase in sardine egg production during periods of high food availability (Bakun and Broad 2002). When energy gain exceeds movement costs, northern stock sardines begin their migration after they reach $20 \mathrm{~cm}$ length and one year of age (Zwolinski and Demer 2012). MacCall (2009) suggests that unlike other species, an important advantage of sardines and anchovies in a fluctuating environment is that they are able to transfer their reproductive energy into the following season, with anchovies moving into estuaries and coastal upwelling areas in the Southern California Bight when their population sizes are reduced, and sardines retreating into the coastal waters off Baja California (Marr 1960, Checkley et al. 2009). When the sardine population shrinks, shoals become mixed with other small pelagic fish like anchovies and mackerel (Bakun and Broad 2002), reducing the effects of predation and thus compensating for the lower population levels (Blaxter and Hunter 1982).

Population changes potentially modify the reproductive potential and are positively associated with age (Hsieh et al. 2006, Anderson et al. 2008). Although changes in ecosystem structure are forced by interannual variability (El Niño/La Niña), the persistence in the atmospheric dynamics of the North Pacific at decadal scales leads to ocean climate regimes with periods of roughly 30 years. Surprisingly, this does not yet appear to have been affected by the global de agua de la CC, junto con una disminución del rotor del esfuerzo del viento y el bombeo de Ekman (Durazo 2009, Durazo et al. 2010). Estas condiciones permanecieron hasta 2006.

Desde principios de la década de 1990, el principal centro de desove de la sardina se encuentra frente a la parte central de California, con desplazamientos zonales y meridionales asociados con los fenómenos de El Niño y La Niña (Lynn 2003, Song et al. 2012). Durante condiciones de La Niña y una CC más intensa en la primavera de 2002, Baumgartner et al. (2008) observaron un movimiento importante hacia fuera de la costa de la subpoblación subártica que vive en aguas subárticas más frías y de menor salinidad. Su zona de desove se extendió hacia el sur hasta punta Eugenia $\left(28^{\circ} \mathrm{N}\right)$, un comportamiento que no fue reflejado por el modelo conceptual de Félix-Uraga et al. (2004). En contraste, debido a una CC más débil y una reducción del transporte de Ekman durante El Niño de 2003, las especies fueron desplazadas hacia el norte de Baja California y centro de California, y hacia la costa. Así mismo, hubo un fuerte reclutamiento en 2004 en aguas frente a California, Oregón y Washington (Lo et al. 2010b, Zwolinski y Demer 2013). En 2003, la estabilidad de la columna de agua probablemente hubiera sido más favorable para el éxito reproductivo de la subpoblación subtropical.

Los cambios biogeográficos relacionados con el hábitat están vinculados a la concentración y densidad del plancton durante las etapas larvarias y adultas, con incrementos en la producción de huevos de sardina durante periodos de alta disponibilidad de alimento (Bakun y Broad 2002). Cuando la ganancia de energía excede los costos de movimiento, las sardinas de la subpoblación norteña empiezan a migrar después de alcanzar $20 \mathrm{~cm}$ de longitud y cumplir un año de edad (Zwolinski y Demer 2012). MacCall (2009) sugiere que, a diferencia de otras especies, una ventaja importante de las sardinas y anchovetas en un ambiente fluctuante es que son capaces de transferir su energía reproductiva a la temporada siguiente. Las anchovetas se trasladan a estuarios y zonas de surgencia costera en la cuenca del Sur de California cuando el tamaño de la población disminuye y las sardinas se trasladan a aguas costeras de Baja California (Marr 1960, Checkley et al. 2009). Cuando la población de sardina disminuye, los cardúmenes se mezclan con otros peces pelágicos menores como la anchoveta y la macarela (Bakun y Broad 2002), para reducir así el efecto de la depredación y compensar el menor nivel poblacional (Blaxter y Hunter 1982).

Los cambios poblacionales pueden modificar el potencial reproductivo y están positivamente relacionados con la edad (Hsieh et al. 2006, Anderson et al. 2008). A pesar de que los cambios en la estructura del ecosistema están forzados por variabilidad interannual (El Niño/La Niña), la persistencia en la dinámica atmosférica del Pacífico Norte a escalas decadales produce regímenes del clima del océano con periodos de unos 30 años. Sorprendentemente, esto aún no parece haber sido afectado por el calentamiento global relacionado con el aumento de gases de efecto invernadero. Un ejemplo de estos 
warming associated with the increase in greenhouse gases. An example of this regime is the regional cooling between 1947 and 1976 that changed both sardine and mackerel age structure in southern California fisheries. Between 1916 and 1959 , the average age of sardine at all ports was $\sim 3.5$ years (Marr 1960, Hsieh et al. 2006). Furthermore, during the collapse of the sardine fishery beginning in the 1940s, the fisheries off California and the Pacific Northwest showed average ages with modes of 2 and 4 years (San Pedro and British Columbia), with a maximum of 8-13 years (Radovich 1982). During 1953, individuals older than 4 years disappeared from the fishery and were not found in the coastal samples of California and Baja California (CalCOFI 1953). Additionally, coastal cruises during the summer and autumn of 1950 to 1952 indicated reproductive failures since 1948 from northern California to Magdalena Bay. The catches off Ensenada in 1952 showed a decrease of $\sim 2.2$ times the 1951 captured biomass (21,330 metric tons $[\mathrm{t}])$ and the disappearance of individuals of 2-4 years belonging to the 1946, 1947, and 1948 age classes (CalCOFI 1953). A similar trend was observed in mackerel in which there was a significant reduction of individuals of age 5 to 1 from 1929 to 1970 (Hsieh et al. 2006).

Sedimentary records of sardine scales have also shown interdecadal fluctuations in the abundance of sardines in the CCS since roughly $400 \mathrm{AD}$. This is likely to reflect changes in recruitment associated with the expansion/contraction of the sardine population (Field et al. 2009). This explains the variations in the sedimentary record of different anoxic basins in the $\mathrm{CC}$, with an expanded population at high densities centered in central California and British Columbia, and contraction in regions around Baja California and the Gulf of California (Parrish and MacCall 1978, Rodríguez-Sánchez et al. 2002). Similar results are observed in mackerel. Fluctuations in abundance (including population collapses) of small pelagic fish appear to be quasi-periodic, with periods centered around $\sim 60$ years (Baumgartner et al. 1992).

\section{SPAWNING REGIONS}

Whereas the biological definition of an exploited stock requires sufficient information to characterize the different spawning areas and the timing of reproduction of the different stocks (table 2; MacCall 1986), the operational definition depends mainly on the area of capture by the fishery. It is important to recognize that the distributions are not stable since decadal fluctuations can alter the location of spawning centers over the latitudinal range of the different stocks (Ahlstrom 1960, 1966). Their ranges can shift over periods from interannual to decadal scales as oceanographic conditions change, such that spawning habitats can be differentiated by their thermohaline properties as shown in figure 3 and table 2. We define a stock here as a group of individuals from a population under human exploitation, with unique biological parameters such as size at age and differences in fecundity that depend mainly on food availability. This is cambios de régimen han sido observados en el enfriamiento regional entre 1947 y 1976 que provocó el cambio en la estructura de edades de sardina y macarela en las pesquerías del sur de California. Entre 1916 y 1959, la edad promedio de sardina en todos los puertos fue $\sim 3.5$ años (Marr 1960, Hsieh et al. 2006). Durante el colapso de la pesquería de sardina a principios de la década de 1940, las pesquerías de California y la costa del Pacífico noroccidental mostraron edades promedio con modas de 2 a 4 años (San Pedro y Columbia Británica), con un máximo de 8-13 años (Radovich 1982). En 1953, los individuos mayores de 4 años desaparecieron de la pesquería y no aparecieron en las muestras de California y Baja California (CalCOFI 1953). Además, datos de cruceros realizados en la costa durante el verano y otoño de 1950 a 1952 indicaron fallas reproductivas desde 1948, desde el norte de California hasta bahía Magdalena. En las capturas frente a Ensenada, la biomasa capturada en 1952 mostró un decremento de $\sim 2.2$ veces en relación con la biomasa capturada en 1951 (21,330 toneladas métricas [t]), así como la desaparición de individuos de 2-4 años pertenecientes a las clases de edad de 1946, 1947 y 1948 (CalCOFI 1953). La macarela mostró una tendencia similar, con una reducción importante en la edad de los individuos, de 5 a 1 años, entre 1929 y 1970 (Hsieh et al. 2006).

Los registros sedimentarios de escamas de sardina también muestran fluctuaciones interdecadales de la abundancia de sardinas en el SCC desde aproximadamente $400 \mathrm{AD}$, lo que probablemente refleja cambios en el reclutamiento asociado con la expansión/contracción de la población (Field et al. 2009). Esto explica las variaciones en el registro sedimentario de diferentes cuencas anóxicas en la $\mathrm{CC}$, con una expansión de población con densidades altas frente al centro de California y la Columbia Británica, y una contracción en regiones de Baja California y el golfo de California (Parrish y MacCall 1978, Rodríguez-Sánchez et al. 2002). Se han observado resultados similares para la macarela. Las fluctuaciones en abundancia (que incluyen los colapsos de poblaciones) de peces pelágicos menores parecen ser casi periódicos, con periodos de $\sim 60$ años (Baumgartner et al. 1992).

\section{REGIONES DE DESOVE}

La definición de una subpoblación explotada require suficiente información para caracterizar las diferentes zonas de desove y la época de reproducción de las diferentes subpoblaciones (tabla 2; MacCall 1986), mientras que la definición operacional depende principalmente de la zona de captura de la pesquería. Es importante reconocer que las distribuciones no son estables ya que las fluctuaciones decadales pueden alterar la ubicación de los centros de desove a lo largo del intervalo latitudinal de las subpoblaciones (Ahlstrom 1960, 1966). Sus rangos meridionales pueden cambiar en periodos de escalas interanuales a decadales según cambian las condiciones oceanográficas, de tal manera que se pueden diferenciar los hábitats de desove por sus propiedades termohalinas 

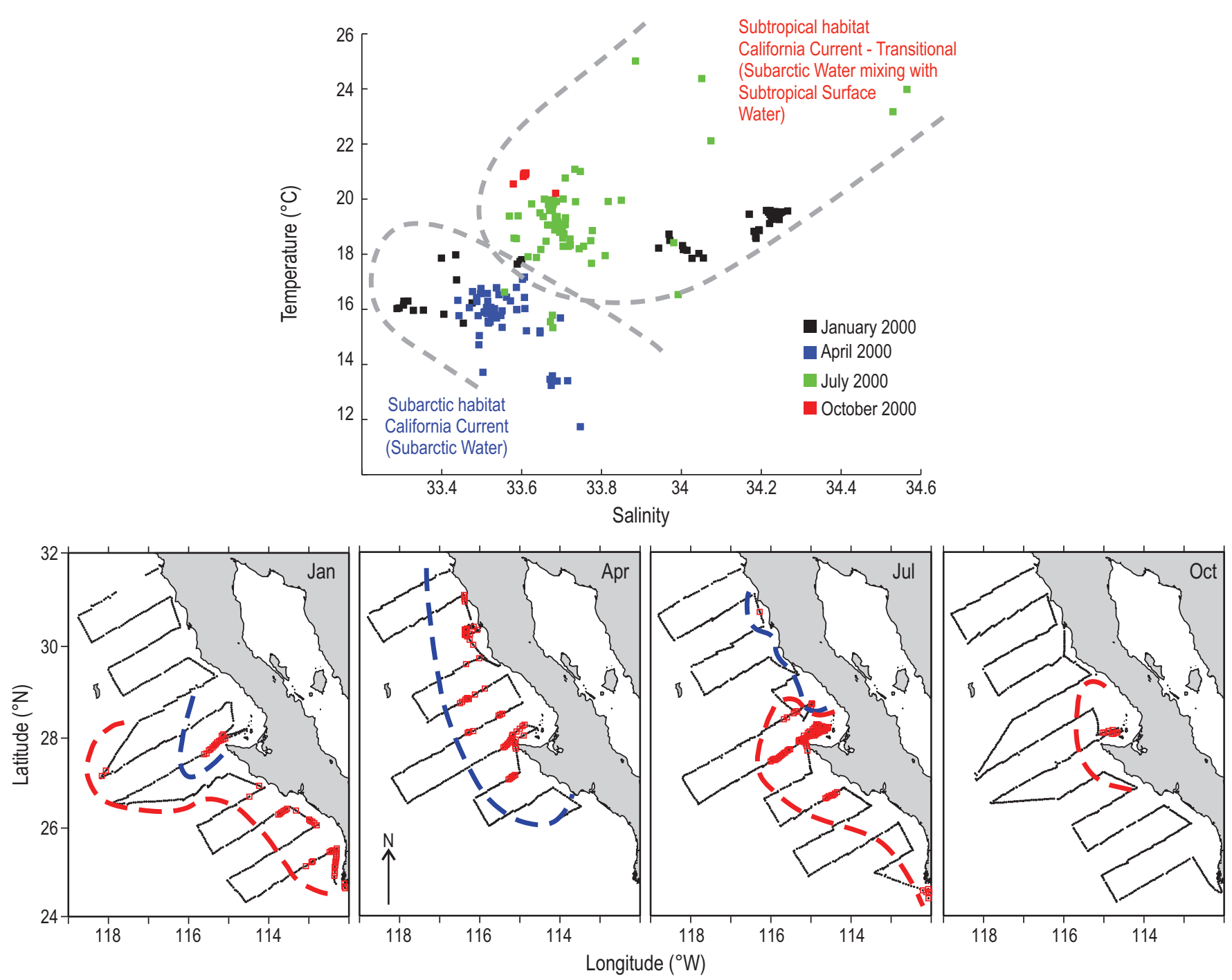

Figure 3. Hypothesis of the latitudinal movements of sardine stocks associated with hydrographic features of the spawning habitat during 2000. In the lower plots, the geographical shifts of spawning habitat of the northern (blue dashed line) and southern (red dashed line) stocks are shown. The spawning habitats, defined as subarctic and subtropical habitats, of the two stocks are differentiated by their thermohaline water properties shown at the top of the figure. Colors on the plot indicate temperature-salinity seasonality during egg collections made by the IMECOCAL program in 2000: January (black), April (blue), July (green), and October (red).

Figura 3. Hipótesis de los movimientos latitudinales de las subpoblaciones de sardina asociados con las características hidrográficas del hábitat de desove durante el año 2000. En las gráficas de abajo se muestran los cambios geográficos del hábitat de desove de la subpoblación del norte (línea discontinua azul) y del sur (línea discontinua roja). Los hábitats, definidos como hábitats subártico y subtropical, de desove de las dos subpoblaciones se diferencian por las propiedades termohalinas del agua que se muestran en la parte superior de la figura. Los colores y números en la gráfica indican la estacionalidad de temperatura y salinidad durante la recolección de huevos realizada por el programa IMECOCAL en 2000: enero (negro), abril (azul), julio (verde) y octubre (rojo).

illustrated by the low fecundity of Pacific sardine in waters off northern Baja California where food availability is limited compared to fish in waters off southern California during 1994 (see fig. 11 in Lo et al. 2005).

The existence of three sardine stocks has been identified in the CCS, from northern California, through the waters off the Baja California Peninsula, and into the Gulf of California (Félix-Uraga et al. 2004, Smith 2005). This is consistent with como se muestra en la figura 3 y la tabla 2. Aquí, definimos a una subpoblación como un grupo de individuos de una población sujeta a explotación humana, con parámetros biológicos singulares tales como tamaño a una edad y diferencias de fecundidad, atributos que dependen principalmente de la disponibilidad de alimento. Esto se demuestra por la baja fecundidad de la sardina del Pacífico en aguas del norte de Baja California donde la disponibilidad de alimento está 
the patterns of movements of sardines established by Clark (1945) through the use of tagging over the period 1935-1944. Morphometric data from otoliths associated with capture temperatures (García-Rodríguez et al. 2011) and cohort analysis (Félix-Uraga et al. 2005) provide further evidence of these three sardine stocks. Morphotypes are almost surely the result of environmental factors that modify the phenotypic characteristics of the organism since there is no evidence of genetic separation of the stocks. While the anchovy population is also considered to consist of three stocks, its genetic structure provided by the analysis of allozymes was found to be highly complex and differentiated (Hedgecock 1986). Marine Plio-Pleistocene deposits and fish remains in coastal Indian middens in southern California indicate that the northern anchovy has been present in the CCS for at least ten million years, while the Pacific sardine is a recent arrival having appeared roughly around 15,000 years ago (Fitch 1969). The characteristics of the stocks of small pelagic fish in the $\mathrm{CC}$ and the Gulf of California are described in table 3 .

The large-scale expansions and contractions of the habitats of small pelagic populations are associated with large changes in biomass. Changing environmental conditions on interdecadal time scales induce progressive changes in abundance and distribution of anchovy and sardine populations (Rodríguez-Sánchez et al. 2002, Lecomte et al. 2004). These changes not only result in displacement of their centers of biomass but also affect the carrying capacity of their habitat in relation to foraging and reproduction (Barange et al. 2009). In the case where a population is contracting, productivity decreases into what is known as refuges to insure survival. For the anchovy these areas have been the waters in the northern CCS off Oregon. This is contrasted with refuge for the Pacific sardine after the collapse of its population, which began in the late $1940 \mathrm{~s}$, that contracted southward into the waters off Baja California where natural mortality and lack of reproductive success reduced the biomass to very low levels (Marr 1960, Rodríguez-Sánchez et al. 2001).

\section{HISTORICAL PERSPECTIVE OF CHANGES IN SMALL PELAGIC POPULATIONS}

The management of small pelagics along the western coast of the Baja California Peninsula is regulated by Norma Oficial Mexicana (Official Mexican Norm) 003-PESC-1993 (DOF 1993) and the SAGARPA (2012) fishery management plan. These regulations cover technical and operational aspects of the fishery. The management plan, in which the goal is to achieve sustainability of the resources and the mitigation of environmental and fishing impacts, is based on a legal minimum catch size. Productivity of the fishery is currently measured as the amount of biomass captured. However, due to unique demographic characteristics and the differential response to environmental conditions of these species, a fishery-independent management plan is needed to limitada en comparación con los individuos en aguas del sur de California durante 1994 (ver fig. 11 en Lo et al. 2005).

Se ha identificado la existencia de tres subpoblaciones de sardina en el SCC, desde el norte de California hasta las aguas frente a la península de Baja California y el golfo de California (Félix-Uraga et al. 2004, Smith 2005). Esto es consistente con los patrones de movimiento establecidos por Clark (1945) para la sardina mediante estudios de marcaje durante el periodo de 1935 a 1944. Los datos morfométricos de otolitos asociados con las temperaturas del agua donde se capturan los individuos (García-Rodríguez et al. 2011) y el análisis de cohortes (Félix-Uraga et al. 2005) proporcionan evidencia adicional de estas tres subpoblaciones de sardina. Los morfotipos probablemente son el resultado de los factores ambientales que modifican las características del organismo ya que no hay evidencia de una separación genética de las subpoblaciones. Aunque la población de anchoveta también consiste de tres subpoblaciones, el análisis de alozimas indica que su estructura genética es muy compleja y diferenciada (Hedgecock 1986). Depósitos marinos del Plio-Pleistoceno y restos de peces ubicados en concheros costeros indican que la anchoveta ha estado presente en el SCC durante por lo menos diez millones de años, mientras que la sardina del Pacífico sólo apareció alrededor de hace 15,000 años (Fitch 1969). Las características de las subpoblaciones de peces pelágicos menores en la $\mathrm{CC}$ y el golfo de California se describen en la tabla 3.

Las expansiones y contracciones a gran escala de los hábitats de las poblaciones de peces pelágicos menores se asocian con cambios considerables de la biomasa. Las variaciones interdecadales en la condición ambiental generan cambios progresivos en la abundancia y distribución de las poblaciones de anchoveta y sardina (Rodríguez-Sánchez et al. 2002, Lecomte et al. 2004). Estos cambios no sólo causan el desplazamiento de sus centros de biomasa sino también afectan la capacidad de acarreo de su hábitat en relación con la alimentación y reproducción (Barange et al. 2009). Cuando una población está en un periodo de contracción, su productividad disminuye y los individuos se mueven hacia refugios para asegurar su supervivencia. Para la anchoveta, estas zonas han sido las aguas en la parte norte del SCC frente a Oregón. En contraste, después del colapso de la población de sardina del Pacífico, que empezó a finales de la década de 1940, ésta se contrajo hacia el sur, a aguas frente a la península de Baja California donde la mortalidad natural y la falta de éxito reproductivo redujeron la biomasa a niveles muy bajos (Marr 1960, Rodríguez-Sánchez et al. 2001).

\section{PERSPECTIVA HISTÓRICA DE LOS CAMBIOS EN LAS POBLACIONES DE PECES PELÁGICOS MENORES}

El manejo de los pelágicos menores a lo largo de la costa occidental de la península de Baja California está regulada por la Norma Oficial Mexicana 003-PESC-1993 (DOF 1993) y el plan de manejo de SAGARPA (2012). Estas regulaciones 
Ciencias Marinas, Vol. 41, No. 4, 2015

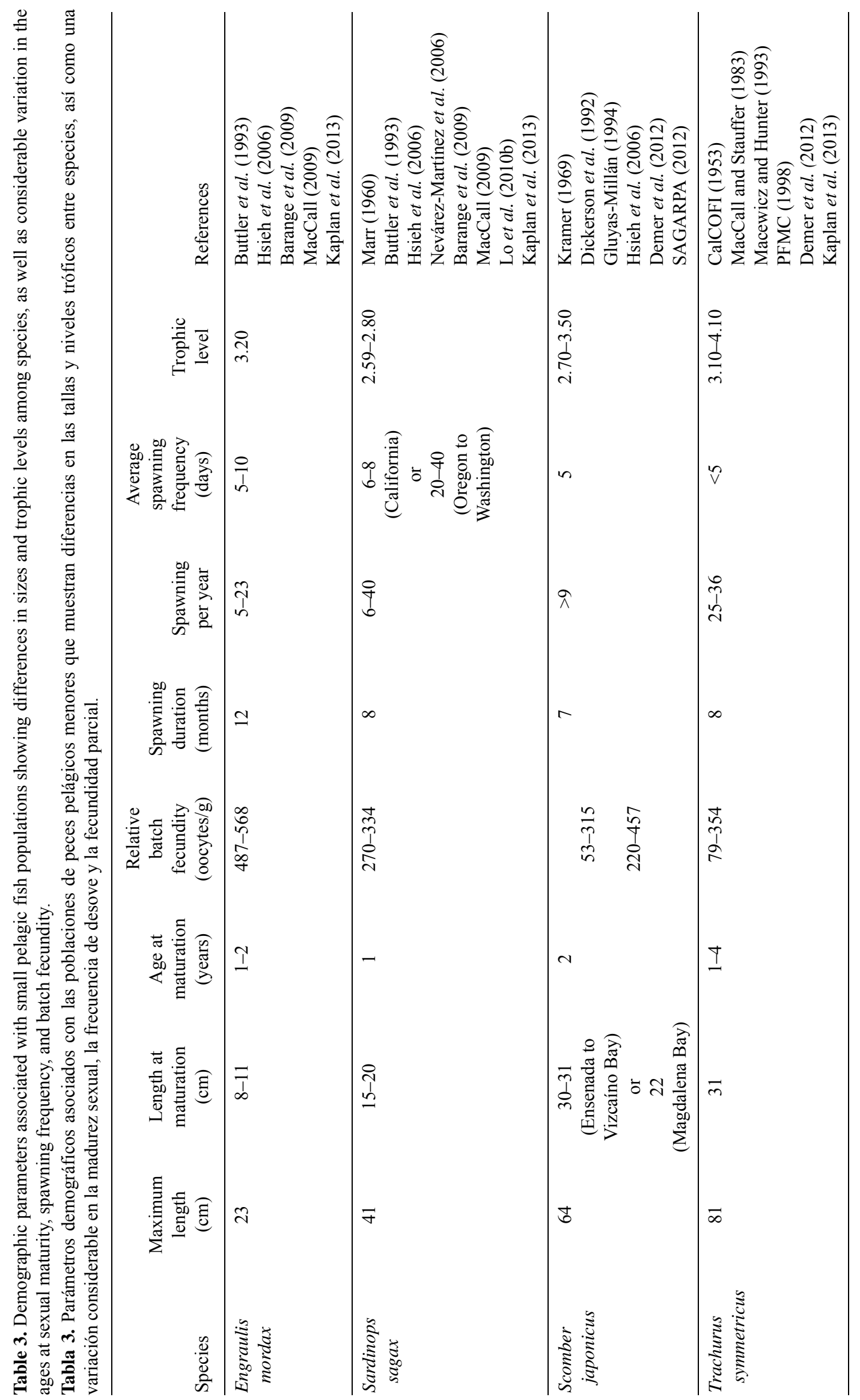


monitor and evaluate each of the stocks found along the peninsula. Legal minimum catch sizes and periods of closures should take into account the status of the population and reproductive peaks in each region.

The waters off the Baja California Peninsula are divided into two fishing units: a northern unit extending from the US-Mexico international border down to Punta Baja and a southern unit running from Punta Eugenia to the area south of Magdalena Bay (Cota-Villavicencio et al. 2010, TorresVillegas 2012). Catches are landed at the ports of Ensenada in the north and San Carlos in Magdalena Bay in the south. Although the operation of the fishing fleet is restricted to a distance of $70 \mathrm{~km}$ from the coast (DOF 1993), it currently operates at a distance of approximately $20 \mathrm{~km}$ offshore due to lack of proper refrigeration (Cota-Villavicencio et al. 2010). The four small pelagic species are recorded in the catches in the northern region, while catches in the Magdalena Bay region consist only of sardine and mackerel (NevárezMartínez et al. 2006). Over the last decade, sardines and mackerels, which are currently under active management, are mostly frozen for shipping overseas or for national consumption (SAGARPA 2012), with biomass of the landings used as an indicator of productivity of the fishery. Anchovy and jack mackerel (Trachurus) are under passive management, with no upper limit having been established for annual catches.

The history of the operation of the fleet based in Ensenada shows four periods: exploration, substitution, development, and consolidation (fig. 4; following the curves

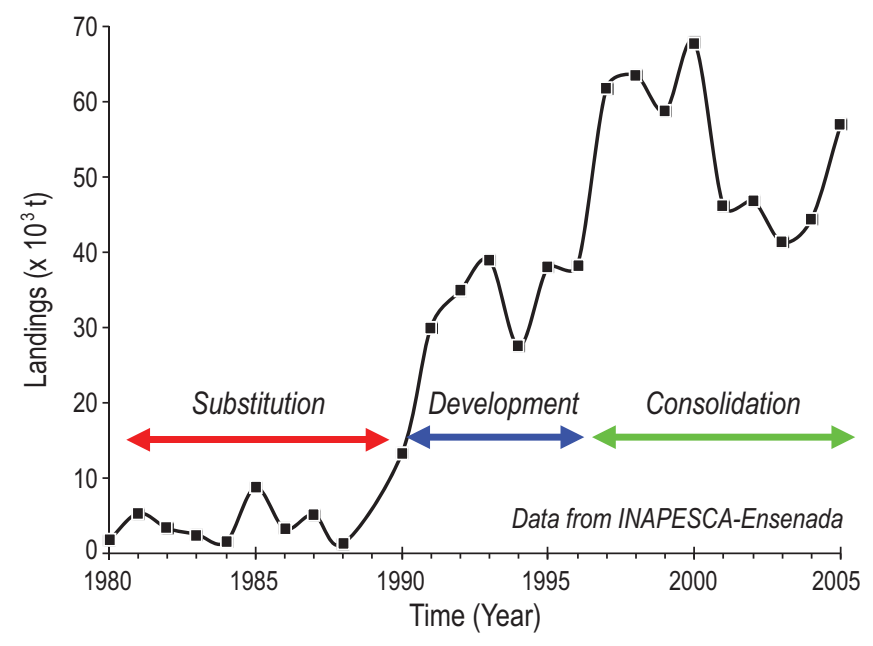

Figure 4. Time series of Pacific sardine (Sardinops sagax) catches made by the fleet operating off the northern portion of the Baja California Peninsula from the coast to $20 \mathrm{~km}$ offshore. The information includes catches off Cedros Island up to 1994, when the fleet ceased operations.

Figura 4. Serie de tiempo de las capturas de sardina del Pacífico (Sardinops sagax) realizadas por la flota que opera frente a la parte norte de la península de Baja California, desde la costa hasta $20 \mathrm{~km}$ mar adentro. La información incluye las capturas de la isla de Cedros hasta 1994, cuando la flota dejó de operar. abarcan aspectos técnicos y operacionales de la pesquería. El plan de manejo, cuyo objetivo es la sustentabilidad de los recursos y la mitigación de los impactos ambientales y pesqueros, se basa en un talla mínima legal de captura. Actualmente la productividad de la pesquería se mide como la cantidad de biomasa capturada; sin embargo, debido a las características demográficas únicas y a la respuesta particular a las condiciones ambientales de estas especies, se requiere de un plan de manejo independiente de la pesquería para monitorear y evaluar cada subpoblación a lo largo de la península. Las tallas mínimas de captura y las épocas de veda deberían tomar en cuenta el estatus de la población y los picos de máxima actividad reproductiva en cada región.

Las aguas frente a la península de Baja California se dividen en dos unidades de pesca: una al norte que se extiende desde la frontera entre Estados Unidos y México hasta punta Baja y una al sur que se extiende desde punta Eugenia hasta al sur de bahía Magdalena (Cota-Villavicencio et al. 2010, Torres-Villegas 2012). Las capturas se desembarcan en el puerto de Ensenada en el norte y en puerto San Carlos en bahía Magdalena en el sur. A pesar de que la operación de la flota pesquera se restringe a una distancia de $70 \mathrm{~km}$ de la costa (DOF 1993), actualmente opera a una distancia de $\sim 20 \mathrm{~km}$ de la costa debido a la falta de refrigeración adecuada (Cota-Villavicencio et al. 2010). Las cuatro especies de pelágicos menores se registran en las capturas de la región norte, pero las capturas en la región de bahía Magdalena consisten de sólo sardina y macarela (Nevárez-Martínez et al. 2006). En la última década, la sardina y macarela, que actualmente están sujetas a un manejo activo, principalmente se congelan para exportación o para consumo nacional (SAGARPA 2012). La biomasa de los desembarques de ambas especies se utiliza como un indicador de la productividad de la pesquería. La anchoveta norteña y el charrito (Trachurus) son de manejo pasivo y no se ha establecido un límite superior para las capturas anuales.

La historia de la operación de la flota de Ensenada muestra cuatro periodos: exploración, sustitución, desarrollo y consolidación (fig. 4; en referencia a la identificación que se presenta en la fig. 7 de Csirke 1985). La etapa de exploración se extendió de 1929 a 1950. La pesca de sardina comenzó en Ensenada en 1929, y se extendió hasta la isla de Cedros y bahía Magdalena en las décadas de 1940 y 1950, respectivamente, debido a la demanda en el mercado local (NevárezMartínez et al. 2006). Al finalizar la década de 1940, la captura de la sardina del Pacífico empezó a disminuir. Estudios de marcaje indicaron un desplazamiento de la subpoblación norteña hacia el norte de Baja California, y mostraron que el recurso carecía de regulación y estaba sujeto a una intensa presión de pesca desde el sur de California hasta la Columbia Británica (Clark 1945). Las capturas en los puertos de California disminuyeron gradualmente y el desplazamiento hacia el norte estaba limitado a aguas del centro de California. El área de desove de la subpoblación norteña se desplaza inicialmente hacia la parte central de Baja 
presented in fig. 7 in Csirke 1985). The exploration phase lasted from 1929 to 1950. Sardine fishing began in Ensenada in 1929 and extended to Cedros Island in the 1940s and to Magdalena Bay in the 1950s motivated by the local market demand (Nevárez-Martínez et al. 2006). By the end of the 1940s sardine catches began to decline. Tagging studies indicated the movement of the northern sardine stock towards northern Baja California and showed that the resource was unregulated and under intense fishing pressure from southern California to British Columbia (Clark 1945). Catches in California ports were gradually declining and northward movement was limited to waters off central California. The change in the northern stock spawning ground towards central Baja California began in 1949 (CalCOFI 1953). By 1952, sardine spawning disappeared north of Point Conception and was found completely displaced towards the region from Punta Baja to the south of Magdalena Bay (Ahlstrom 1960). Every year afterwards ended in a regional reproductive failure due to the absence of sufficient food supply coupled with unregulated fishing and the unfavorable environmental conditions (Marr 1960) until the recovery that began in the 1980 s, which was emphatically confirmed by the appearance of sardines in British Columbia waters in 1992 (McFarlane and Beamish 2001).

With the collapse of the Pacific sardine in the California fishery, a substitution stage began. This was characterized on the one hand by the exploration of other resources such as anchovy and on the other by the movement of the Mexican fleet to the Gulf of California (Nevárez-Martínez et al. 2006). The catch of other small pelagics became important during the period of sardine collapse, with an increase and expansion of the northern anchovy biomass in 1950-1952, which eventually became the most important fishery off California (CalCOFI 1953). The larval distribution of T. symmetricus indicated a spawning nucleus near the center of the Baja California Peninsula (between Point Conception and Punta Baja), located between 150 and $600 \mathrm{~km}$ offshore from March to July (CalCOFI 1953). The catches of jack mackerel showed an increase in size from 20.3 to $38.1 \mathrm{~cm}$ in southern California, with predominant ages of 2 years and a maximum of 6. During this period, Pacific mackerel larvae were also found throughout the year, in the same region where jack mackerel were spawning, with peaks in April and May (CalCOFI 1953). The catch of Pacific mackerel in southern California showed a similar behavior to that of sardine, including the collapse of the fishery (Parrish and MacCall 1978). Mackerel, anchovy, and jack mackerel showed a decrease in their catches in California while becoming more important in Baja California (CalCOFI 1953). Anchovy landings in Ensenada acquired more importance due to the collapse of Peruvian anchovy in the early 1970s, and the demand resulted in intensive exploitation off northern Baja California (Nevárez-Martínez et al. 2006), reaching a peak in 1981 with $>2.5 \times 10^{5} \mathrm{t}$ (see fig. 1 in Cota-Villavicencio et al. 2010).
California en 1949 (CalCOFI 1953). Para 1952, la sardina había dejado de desovar al norte de punta Concepción y se había desplazado hacia la región de punta Baja al sur de bahía Magdalena (Ahlstrom 1960). En cada año subsiguiente se observaron fracasos reproductivos a escala regional debido a la ausencia de alimento, a su pesca no regulada y a condiciones ambientales desfavorables (Marr 1960) hasta el inicio de su recuperación en la década de 1980, confirmado enfáticamente por la reaparición de sardinas en aguas de Columbia Británica en 1992 (McFarlane y Beamish 2001).

Con el colapso de la pesquería de sardina del Pacífico en California, comenzó una etapa de sustitución, que se caracterizó, por un lado, por la exploración de otros recursos como la anchoveta y, por otro, por el traslado de la flota mexicana al golfo de California (Nevárez-Martínez et al. 2006). La captura de otros pelágicos menores se volvió importante durante el periodo en que colapsó la sardina, con un aumento y expansión de la biomasa de anchoveta entre 1950 y 1952, que eventualmente se convirtió en la pesquería más importante de California (CalCOFI 1953). La distribución de las larvas de T. symmetricus indicaban un núcleo de desove en la parte central de la península de Baja California (entre punta Concepción y punta Baja), ubicada entre 150 y $600 \mathrm{~km}$ de la costa durante marzo a julio (CalCOFI 1953). Las capturas del charrito en el sur de California mostraron un aumento en el tamaño de los individuos, de 20.3 a $38.1 \mathrm{~cm}$, con una edad predominante de 2 años y máxima de 6 . Durante este periodo, también se encontraron larvas de la macarela del Pacífico durante todo el año, en la misma región donde el charrito realizaba el desove, con abundancias máximas en abril y mayo (CalCOFI 1953). La captura de macarela del Pacífico mostró un comportamiento similar al de la sardina, e incluso el colapso de su pesquería (Parrish y MacCall 1978). Las capturas de macarela, anchoveta y charrito disminuyeron en California pero aumentaron en Baja California (CalCOFI 1953). Los desembarques de anchoveta en Ensenada adquirieron mayor importancia debido al colapso de la anchoveta peruana a principios de la década de 1970 , y la demanda provocó una explotación intensiva en el norte de Baja California (Nevárez-Martínez et al. 2006), con una captura máxima de $>2.5 \times 10^{5} \mathrm{t}$ alcanzada en 1981 (ver fig. 1 en CotaVillavicencio et al. 2010).

En comparación con otros pelágicos menores, la anchoveta muestra mayor sensibilidad a cambios ambientales, los cuales reducen la supervivencia y el reclutamiento de sus juveniles. Con el incremento gradual de temperatura en el SCC después de 1976, el hábitat de desove de la anchoveta se contrajo hacia el norte. Las capturas en Baja California (individuos de edad 0 y 1 año) disminuyeron en importancia con el desplazamiento de sus áreas de desove al sur de California (MacCall 2009). Butler et al. (1993) sugirieron que las mayores temperaturas podrían haber disminuido las tasas de crecimiento de las etapas larvales tempranas después de agotar sus reservas del saco vitelino, lo que redujo el tamaño de las población de larvas en un $74 \%$. Durante este periodo, las 
Compared to other small pelagics, anchovies show a greater sensitivity to environmental effects, which reduce the survival and recruitment of juveniles. With the gradual increase in temperatures in the CCS after 1976, the spawning habitat of anchovies retreated northward. Catches off Baja California (0-1 year individuals) decreased in importance with the movement of their spawning grounds into southern California (MacCall 2009). Butler et al. (1993) suggested that warmer temperatures may have reduced the growth rates of early larval stages after the exhaustion of their yolk reserves, thus reducing the size of the larval population by $74 \%$. During this period the occasional catches of sardine and mackerel increased, giving way to the development stage of their fisheries in Mexico (Cota-Villavicencio et al. 2010).

In the late 1980s, the anchovy fishery off Baja California collapsed at the same time that the spawning area moved northward into southern California. The presence of anchovy was widely distributed off southern California during 1997 and 2005-2008 (Bjorkstedt et al. 2010). However, there were years in which spawning was either confined to coastal areas or virtually absent. There has been significant spawning of northern anchovy off Baja California at least since 2006. Data from the Mexican Program for California Current Research (IMECOCAL, for its Spanish acronym) indicated important spawning off Baja California by $T$. symmetricus particularly in the winter of 2001, when there was no spawning off California. Jack mackerel spawning areas are widely distributed in the oceanic waters off Baja California, showing a meridional migration pattern during spring/summer and fall/winter. Their presence in the CalCOFI region has been limited to relatively low densities with distribution overlapping areas of sardine spawning during warm years off both southern California and northern Baja California (Baumgartner et al. 2008, Bjorkstedt et al. 2010).

Félix-Uraga et al. (1996) proposed that the significant recruitment of sardines after $1984\left(>1.5 \times 10^{8}\right.$ individuals $)$ in the Magdalena Bay fishery was a result of a large increase in abundance as indicated by the 16 -fold increase in landings during the sardine recovery in the period 1984-1994. Older individuals ( $>5$ years) were observed in the Magdalena Bay catches in southern Baja California in 1983, 1988, and 1992, leading to strong recruitment in the following years (FélixUraga et al. 1996, 2004). The year of increased catches in Ensenada was 1989 (8566 t), favored by a shift to the north in the distribution of the subtropical stock $\left(17-20^{\circ} \mathrm{C}\right.$ during the fall) with a subsequent decrease in landings in Magdalena Bay during the subsequent years, from 1989 to 1993 (FélixUraga et al. 1996). The trend in the Magdalena Bay recruitment remained high through 2004, when the recruitment and the catches began a downward trend until 2010 (SAGARPA 2012). Availability of the cold subarctic stock off Ensenada was reduced in the early 1990s due to its displacement northward into southern California (Félix-Uraga et al. 2004). This result reveals two elements needed to understand the population structure and movements of the sardines: (1) the capturas ocasionales de sardina y macarela aumentaron, dando paso a la etapa de desarrollo de sus pesquerías en México (Cota-Villavicencio et al. 2010).

A finales de la década de 1980, la pesquería de anchoveta en Baja California colapsó al mismo tiempo que el área de desove se desplazó hacia el norte, al sur de California. En esta region, el desove presentó una amplia distribución en 1997 y de 2005 a 2008, aunque en algunos años se confinó a aguas costeras o fue casi nulo (Bjorkstedt et al. 2010). En Baja California se ha registrado una importante actividad de desove de la anchoveta desde 2006. Datos del programa Investigaciones Mexicanas de la Corriente de California (IMECOCAL) indican desoves importantes del charrito frente a Baja California especialmente en el invierno de 2001, cuando no se registró en California. Las áreas de desove del charrito están ampliamente distribuidas en aguas oceánicas de Baja California e indican un patrón de migración meridional en primavera/verano y otoño/invierno. $\mathrm{Su}$ presencia en la región de CalCOFI ha sido limitada a densidades relativamente bajas y durante años cálidos su distribución traslapa con zonas de desove de la sardina tanto frente al sur de California como al norte de Baja California (Baumgartner et al. 2008, Bjorkstedt et al. 2010).

Félix-Uraga et al. (1996) sugirieron que un incremento en el reclutamiento de sardinas posterior a $1984\left(>1.5 \times 10^{8}\right.$ individuos) en la pesquería de bahía Magdalena fue resultado de un aumento considerable en las capturas. El incremento en la abundancia de la sardina fue detectado por el aumento (de hasta 16 veces) en las capturas durante el periodo de recuperación de la pesquería de 1984 a 1994. Se observaron individuos de mayor edad ( $>5$ años) en las capturas de bahía Magdalena en 1983, 1988 y 1992, seguido por un fuerte reclutamento en los años subsiguientes (Félix-Uraga et al. 1996, 2004). El año de mayores capturas en Ensenada fue 1989 (8566 t), favorecido por un desplazamiento hacia el norte de la distribución de la subpoblación subtropical $\left(17-20^{\circ} \mathrm{C}\right.$ en otoño), con la consecuente disminución de los desembarques en bahía Magdalena en los años posteriores, de 1989 a 1993 (Félix-Uraga et al. 1996). En bahía Magdalena, el reclutamiento presentó una tendencia al alza hasta 2004, a partir del cual el reclutamiento y las capturas presentaron una tendencia a la baja hasta 2010 (SAGARPA 2012). La disponibilidad de la subpoblación subártica frente a Ensenada disminuyó a principios de la década de 1990 debido a su desplazamiento hacia el norte, al sur de California (Félix-Uraga et al. 2004). Este resultado muestra dos elementos que se necesitan para entender la estructura poblacional y el movimiento de la sardina: (1) la información requerida para discriminar entre las dos subpoblaciones en las capturas de Ensenada es limitada antes de 1990 ya que la pesca se enfocaba más en la anchoveta que en la sardina, y (2) con la recuperación de la población de la sardina, ya perceptible a fines de la década de 1980, tanto la subpoblación subártica como la subtropical habían iniciado desplazamientos estacionales hacia el norte a lo largo de la costa, con la 
information needed to discriminate between the two stocks from sardine landings in Ensenada prior to 1990 is limited since the fishing was focused on anchovies rather than sardines, and (2) upon recovery of the sardine population, underway by the late 1980 s, both the subarctic and subtropical stocks had begun seasonal northward movements along the coast with the subarctic stock reaching as far as British Columbia (MacFarlane and Beamish 2001, Lo et al. 2010b).

Off Ensenada, the consolidation stage of the fishery began in the early 1990s and continued into 2013. Sardine landings have remained above a threshold of 22,500 $\mathrm{t}$ (1994), with peaks in 1997 and 2011 of 68,000 and 70,000 t, respectively (Félix-Uraga et al. 1996, Zwolinski and Demer 2013). The catch of Pacific mackerel also increased in this period and eventually reached a maximum of $\sim 51,000 \mathrm{t}$ in 1998 (Nevárez-Martínez et al. 2006, Cota-Villavicencio et al. 2010). Lo et al. (1996) suggest that the increase in the sardine spawning area during spring favored the biomass of the northern subarctic stock, with spawning patterns associated with filaments of cold water $\left(13-14.5^{\circ} \mathrm{C}\right)$ in California (including the area around Monterey Bay and Piedras Blancas) and, to a lesser extent, off Baja California, south to Vizcaíno Bay.

The regional monitoring conducted with underway temperature and salinity sensors, coupled with the collection of near-surface fish eggs using a continuous underway fish egg sampler (CUFES, Checkley et al. 2000), indicate the thermohaline ranges and the selection of the reproductive habitat by the adults. Given the relatively weak currents of the CC $\left(<30 \mathrm{~cm} \mathrm{~s}^{-1}\right)$ and the resulting limited horizontal transport of fish eggs $\left(<26 \mathrm{~km} \mathrm{~d}^{-1}\right)$, the spawning areas clearly indicate the presence of adults. Here, we hypothesize a synchronous latitudinal movement of the spawning habitat of the northern and southern stocks of Pacific sardine off Baja California defined by temperature and salinity (fig. 3). This idea is consistent with the spatial and temporal pattern of the movement of these stocks proposed in the conceptual model of FélixUraga et al. (2004) and corroborated by the predictive model of the potential habitat of sardine (Demer and Zwolinski 2014). The southward movement of the northern stock is associated with the equatorward transport of the cooler subarctic water down to Punta Eugenia during the cold La Niña conditions in winter and spring, while the southern stock dominates the catch in this region in summer and fall (Baumgartner et al. 2008, Checkley et al. 2009). However the availability of the cold subarctic stock is reduced because of the limited offshore operation by the fleet (CotaVillavicencio et al. 2010).

Based on histological observations of sardine gonads from the commercial catch, the northern stock spawns during winter and spring (SAGARPA 2012). Peak egg production occurs in April, although INAPESCA states that it may occur during March or February in some years. However, because sardine catches are limited to $20 \mathrm{~km}$ from the coast, these estimates may be strongly biased since sardines move subpoblación subártica llegando hasta la Columbia Británica (MacFarlane y Beamish 2001, Lo et al. 2010b).

Frente a Ensenada, la etapa de consolidación de la pesquería comenzó a principios de la década de 1990 y continuó hasta 2013. Los desembarques de sardina han permanecido por arriba de un umbral de 22,500 t (1994), con capturas máximas en 1997 y 2011 de 68,000 y 70,000 t, respectivamente (Félix-Uraga et al. 1996, Zwolinski y Demer 2013). La captura de la macarela del Pacífico también aumentó durante este periodo y eventualmente alcanzó un máximo de 51,000 t en 1998 (Nevárez-Martínez et al. 2006, CotaVillavicencio et al. 2010). Lo et al. (1996) sugirieron que la biomasa de la subpoblación norteña subártica de la sardina fue favorecida por un incremento en el área de desove en primavera, los cuales estuvieron asociados a filamentos de agua fría $\left(13-14.5^{\circ} \mathrm{C}\right)$ en California (que incluye el área alrededor de la bahía de Monterey y Piedras Blancas) y, en menor medida, frente a la península de Baja California, alrededor de bahía Vizcaíno.

El monitoreo regional realizado con sensores de temperatura y salinidad a bordo de embarcaciones en movimiento, junto con la recolección de huevos de peces cerca de la superficie con un sistema para el muestreo continuo de huevos de peces (CUFES, por sus siglas en inglés; Checkley et al. 2000), muestran los intervalos termohalinos y de selección del hábitat por los adultos. Dadas las corrientes relativamente débiles de la CC $\left(<30 \mathrm{~cm} \mathrm{~s}^{-1}\right)$ y el resultante transporte horizontal limitado de huevos de peces $\left(<26 \mathrm{~km} \mathrm{~d}^{-1}\right)$, las áreas de desove claramente indican la presencia de adultos. Aquí se propone la hipótesis de un movimiento latitudinal sincrónico del hábitat de desove de las subpoblaciones norteña y sureña de la sardina del Pacífico frente a la península de Baja California, hábitats definidos por la temperatura y salinidad (fig. 3). Esta idea es consistente con el patrón de movimiento espacial y temporal de estas subpoblaciones propuesto en el modelo conceptual de Félix-Uraga et al. (2004) y corroborado por el modelo predictivo del hábitat potencial de la sardina (Demer y Zwolinski 2014). El desplazamiento hacia el sur de la subpoblación norteña está asociado con el transporte hacia el ecuador de agua fría del subártico hasta punta Eugenia durante las condiciones frías de La Niña en invierno y primavera, mientras que la subpoblación sureña domina las capturas en esta región en verano y otoño (Baumgartner et al. 2008, Checkley et al. 2009). No obstante, la disponibilidad de la subpoblación subártica es menor debido a la limitada operación de la flota fuera de la costa (Cota-Villavicencio et al. 2010).

Con base en observaciones histológicas de las gónadas de sardinas provenientes de la captura comercial, la subpoblación norteña desova en invierno y primavera (SAGARPA 2012). La máxima producción de huevos ocurre en abril, aunque INAPESCA menciona que en algunos años puede ocurrir en marzo o febrero; sin embargo, como las capturas de sardina están limitadas a $20 \mathrm{~km}$ de la costa, estas estimaciones podrían estar fuertemente sesgadas ya que en primavera, las 
offshore to spawn during spring to avoid the recently upwelled, colder water nearshore. Baumgartner et al. (2008) showed the distribution and relative concentration of eggs in CUFES samples occurring outside the upwelling fronts in spring, parallel to the coast between 50 and $200 \mathrm{~km}$ offshore. The information of the spawning habitat inferred by the presence of eggs indicated a high probability of finding reproductive adults of sardines that were not available to the fishing fleet.

\section{DISCUSSION}

We have presented a review of the life cycle, distribution, and relationship to ocean climate conditions of four species of small pelagic fishes along the west coast of the Baja California Peninsula. This region is highly heterogeneous in terms of hydrography, bathymetry, and productivity, and has a wide range of habitats that vary over space (latitudinal and onshore/offshore) and time (from seasonal and interannual to interdecadal scales) for pelagic species along the coast. Habitats are modified by alongshore winds, by wind stress curl, and by the interactions between currents and capes, particularly the prominent cape formed by Punta Eugenia that forms the southern boundary of Vizcaíno Bay in central Baja California. Forcing by alongshore equatorward winds produces upwelling along the coast that provides the nearshore habitat preferred by anchovies. Offshore of the upwelling area, a frontal zone offers the necessary food supply for sardine and Pacific mackerel that prefer similar habitat conditions. The oligotrophic region away from the coast, driven mainly by wind stress curl, is occupied by the larger size and highly mobile jack mackerel. Habitat selection by these different species provides a natural system of organization for their separation into units that are managed as fishery stocks. Although the current management plan calls for monitoring of biomass for the actively managed stocks, information is not yet available in regard to efforts to determine the biomass of sardine or Pacific mackerel off the Baja California Peninsula. However, this information should be forthcoming in the near future with the new $62-\mathrm{m}$ fisheries research vessel recently put into service that is now equipped with hydroacoustic instruments, fishing gear, and CUFES. A fundamental criterion is still the minimum size requirement for individual fish. The overall objective of the management plan is to insure continuity of the fisheries resources by establishing levels of acceptable exploitation to permit sustainable yields of species under active management.

One of the paradigms in fisheries oceanography is "Spawning stock biomass (SSB) is a suitable proxy for reproductive potential of a stock" (Leggett and Frank 2008). The reproductive potential of a fishery stock is often judged by the number of recruits to the adult population. Total egg production based on estimated rates of egg mortality and temperature-based time to hatching can be used as a proxy for reproductive potential that is generally correlated to sardinas se trasladan fuera de la costa para desovar y evitar las aguas frías surgidas cerca a la costa. En muestras obtenidas con el sistema CUFES en primavera fuera de los frentes de surgencia y paralelos a la costa, Baumgartner et al. (2008) mostraron que la distribución y concentración relativa de huevos ocurrió entre 50 y $200 \mathrm{~km}$ de la costa. La información del hábitat de desove inferido de la presencia de huevos indicó una alta probabilidad de encontrar adultos reproductivos de sardina fuera del alcance de la flota pesquera.

\section{Discusión}

Hemos presentado una revisión del ciclo de vida de cuatro especies de pelágicos menores, su relación con el clima del océano y su distribución a lo largo de la costa occidental de la península de Baja California. Esta región es muy heterogénea en cuanto a la hidrografía, batimetría y productividad, y posee una amplia gama de hábitats que varían en el espacio (latitudinal y hacia/fuera de la costa) y el tiempo (de escalas estacionales e interanuales a interdecadales) que son ocupados por peces pelágicos a lo largo de la costa. Los hábitats son modificados por vientos paralelos a la costa, el rotor del esfuerzo del viento y las interacciones entre las corrientes y los cabos, especialmente el cabo prominente formado por punta Eugenia que forma el límite sur de la bahía Vizcaíno en la parte central de la península. El forzamiento por vientos paralelos a la costa en dirección al ecuador genera surgencias costeras que proporcionan el hábitat preferencial de la anchoveta. Mar adentro del área de surgencia, una zona frontal ofrece el suministro de alimentos necesarios para la sardina y la macarela del Pacífico que prefieren condiciones similares en sus hábitats. La región oligotrófica fuera de la costa, mantenida principalmente por el rotor del esfuerzo del viento, es ocupada por T. symmetricus, la especie de mayor tamaño y altamente móvil. La selección del hábitat por las especies descritas proporciona un sistema natural de organización para su separación en unidades que se manejan como subpoblaciones pesqueras. El plan de manejo actual requiere un monitoreo de la biomasa para las especies bajo manejo activo de su pesquería, aunque en el momento no se dispone de información en cuanto a los esfuerzos para cuantificar la biomasa de la sardina y macarela del Pacífico en la costa de la península de Baja California; sin embargo, esta información se podrá recabar en un futuro cercano con el nuevo barco oceanográfico de $62 \mathrm{~m}$ que recientemente fue puesto en servicio, equipado con instrumentos hidroacústicos, artes de pesca y un sistema CUFES. Un criterio fundamental sigue siendo el requerimiento de una talla mínima para los peces capturados. El objetivo global del plan de manejo es asegurar la continuidad de los recursos pesqueros al establecer niveles aceptables de explotación, que permiten rendimientos sustentables de las especies sujetas a un manejo activo.

Uno de las paradigmas en la oceanografía pesquera es que la biomasa desovante (spawning stock biomass, SSB) es un indicador adecuado del potencial reproductivo de una 
spawning biomass, although the daily egg production method (Lasker 1985) used to estimate the spawning biomass requires knowledge of adult parameters that include batch fecundity, mean weight, and proportion of females and their frequency of spawning. Even so, the relationship between spawning biomass and egg production does not provide a direct estimate of productivity leading to recruitment. Recruitment is also subject to unfavorable (or more favorable) environmental conditions such as offshore (or onshore) transport of eggs and larvae, which may result in loss (or improved survival) of eggs and larvae, as well as availability (or lack) of food for newly hatched larvae and favorable (or unfavorable) conditions for the survival of juveniles (prerecruits). Leggett and Frank (2008) cited Yaragina and Marshall (2000) to note that indeed "a search for a comprehensive understanding of the factors regulating variability in reproductive potential, independent of SSB, may be as complex and as inextricably linked to environmental and ecological factors, as are the causes in egg and larval survival."

The Ensenada sardine landings (port of El Sauzal) from March to June 2002 included juveniles (pre-recruits) less than $15 \mathrm{~cm}$ long (which is smaller than the legal size) less than 1 year old, and $<50 \mathrm{~g}$ weight (fig. 5), and suggested a pattern of recruitment that depends on the previous year's spawning (February-July 2001). There is a significant contrast in size and weight between the first and second subpoblación (Leggett y Frank 2008). El potencial reproductivo de una subpoblación pesquera es frecuentemente juzgado por el número de reclutas que se incorporan a la población adulta. Se puede usar la producción total de huevos basada en la tasa estimada de mortalidad de huevos y el tiempo de incubación (dependiente de la temperatura) como un indicador del potencial reproductivo que generalmente se correlaciona con la biomasa desovante. A pesar de que el método de producción diaria de huevos (Lasker 1985) es usado para estimar la biomasa desovante, el método requiere conocimiento de los parámetros de adultos, entre ellos la fecundidad parcial, el peso promedio y la proporción de hembras y su frecuencia de desove. Aun así, la relación entre la biomasa desovante y la producción de huevos no proporciona una estimación directa de la productividad que conduce al reclutamiento. El reclutamiento también está sujeto a condiciones ambientales desfavorables (o favorables) tales como el transporte hacia fuera de la costa (o hacia la costa) de huevos y larvas, que puede resultar en su pérdida (o supervivencia), así como en la disponibilidad (o falta) de alimento para larvas recién eclosionadas y en condiciones favorables (o desfavorables) para la supervivencia de individuos juveniles (prereclutas). Leggett y Frank (2008) citaron a Yaragina y Marshall (2000) para indicar que "la búsqueda de una comprensión integral de los factores que regulan la variabilidad del potencial reproductivo, independiente de la SSB, puede ser tan

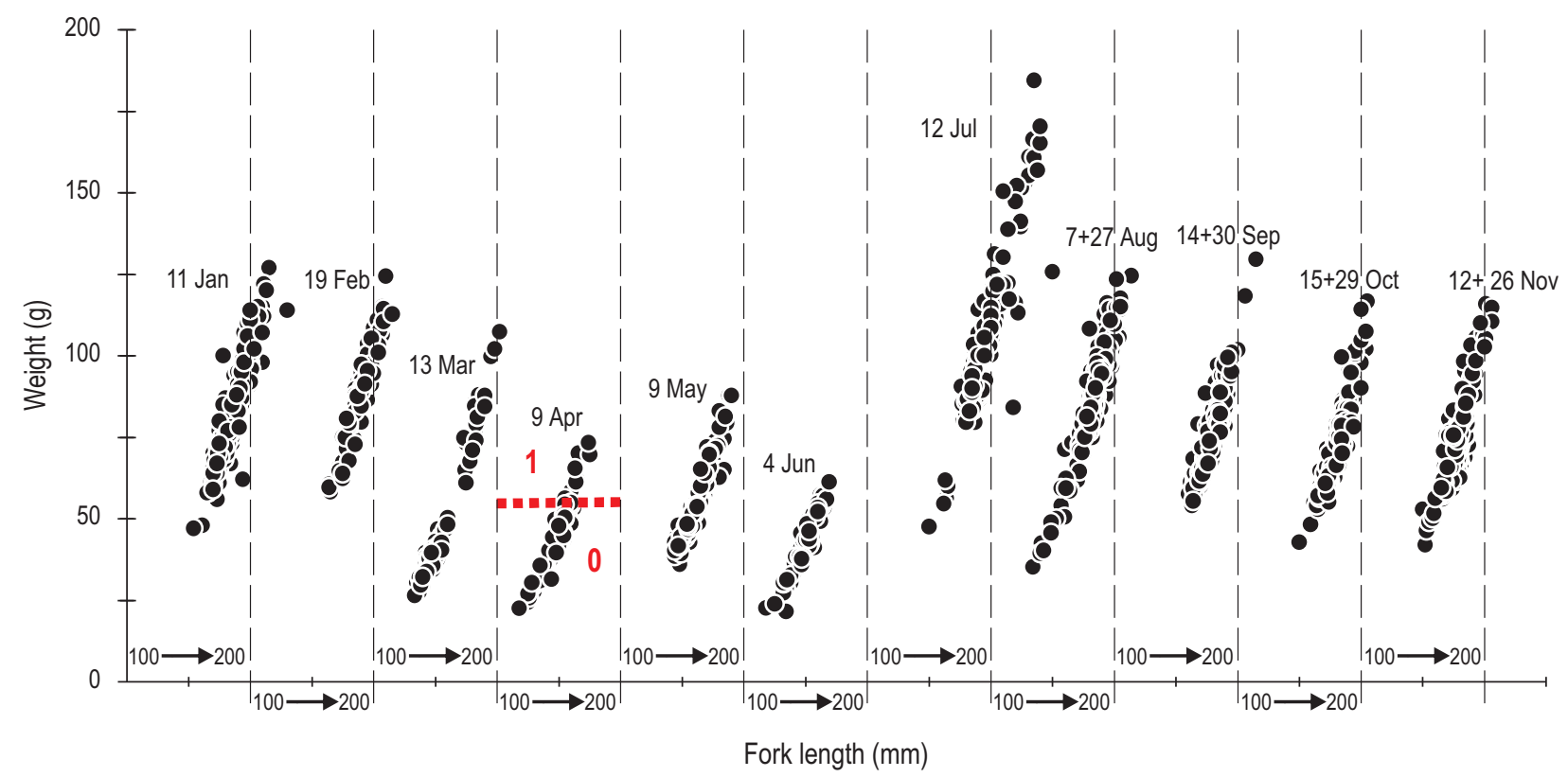

Figure 5. Length-weight relationship for monthly samples of Pacific sardine (Sardinops sagax) landings at the port of El Sauzal, just north of Ensenada, from January through November 2002. The heavy dashed red line separates the age groups of 0 and 1 year-old fish in the April sample. The length scales run from 100 to $200 \mathrm{~mm}$ for each sample.

Figura 5. Relación entre longitud y peso para las muestras mensuales de sardina del Pacífico (Sardinops sagax) en los desembarques del puerto de El Sauzal, justo al norte de Ensenada, de enero a noviembre de 2002. La línea discontinua roja separa los grupos de peces de 0 y 1 año de edad en la muestra de abril. Las escalas de longitud son de 100 a $200 \mathrm{~mm}$ para cada muestra. 


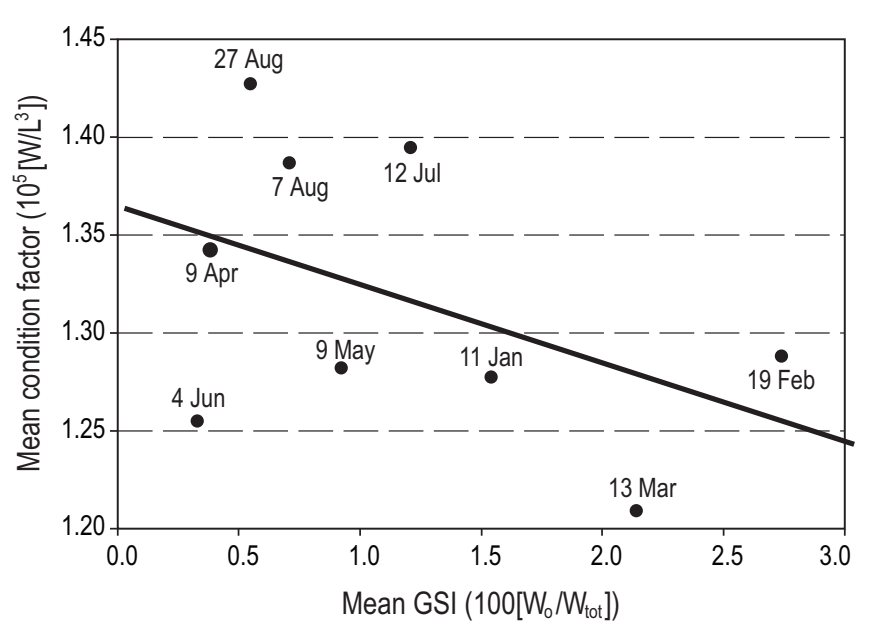

Figure 6. Mean condition factor $\left(\mathrm{W}=\right.$ total weight, $\mathrm{L}^{3}=[$ fork length $\left.]^{3}\right)$ vs mean gonosomatic index $\left(\mathrm{GSI} ; \mathrm{W}_{\mathrm{o}}=\right.$ weight of ovary; $\mathrm{W}_{\text {tot }}=$ total weight).

Figura 6. Factor de condición promedio $\left(\mathrm{W}=\right.$ peso total, $\mathrm{L}^{3}=$ [longitud furcal $]^{3}$ ) vs el índice gonadosomático promedio (GSI; $\mathrm{W}_{\mathrm{o}}=$ peso del ovario; $\mathrm{W}_{\text {tot }}=$ peso total).

semesters of the year. There is a significant contrast in size and weight between the first and second semesters of the year. The dominance of the subtropical sardine stock in the catch resulted in an abrupt shift to a larger size in July (shown in fig. 5) and their condition improved in July and August relative to the first semester catch dominated by the subarctic stock (shown in fig. 6). The reduction in size of the sardines in the August through November samples seen in figure 5 is likely to have been produced by the fishery, as argued by Hsieh et al. (2006).

Landings of the Ensenada fishing fleet suggest that the availability of sardines depends on the latitudinal movements of the stocks in the CCS. Figure 7 shows that the long-term monthly means of catches lag SST by one to two months, indicating that the seasonal modification of habitat conditions induces synchronous migration of the subarctic and subtropical stocks in agreement with the conceptual model of movement of stocks presented by Félix-Uraga et al. (2004). This could be a response of the biomass of both stocks following the latitudinal movement of their characteristic habitats. In summer and fall, the southern stock moves as far north as San Pedro, California, and is compressed into the coast by the seasonal warming. In winter, a portion of the cold northern stock moves southward into northern and central Baja California and then moves offshore to spawn during spring to avoid the cold upwelled water along the coast, resulting in a much lower catch during April, May, and June, as shown in figure 5 for 2002. It is also noteworthy that 0 -aged fish composed roughly one half of the landings in this period (fig. 5). This suggests that the inshore area likely acts as a refuge

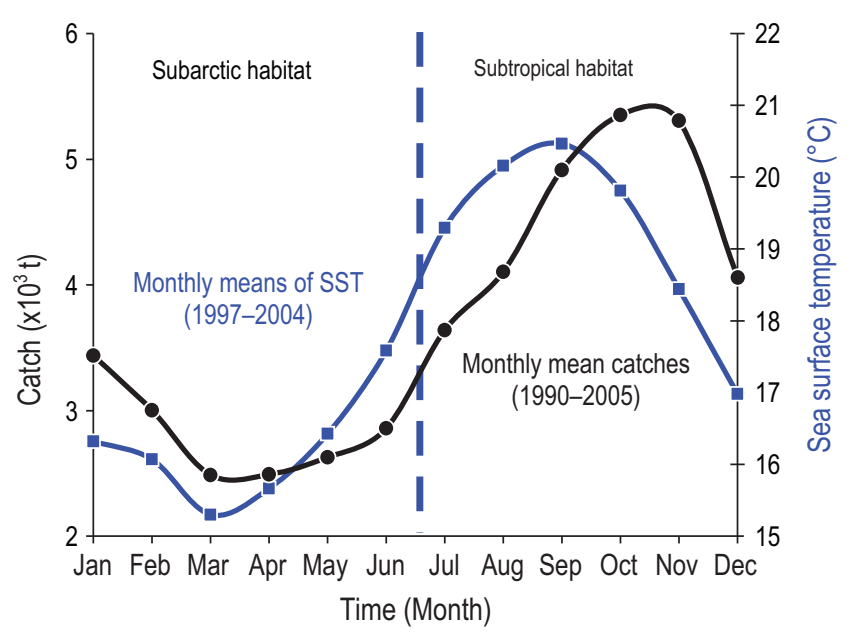

Figure 7. Seasonal pattern of Pacific sardine (Sardinops sagax) catches in northern Baja California waters (1990-2005, black line), obtained from the monthly catch data provided by the Fishing Subdelegation in Ensenada (Baja California, Mexico). Monthly averages of sea surface temperature (SST, blue line) $\sim 80 \mathrm{~km}$ off the coast near $31^{\circ} \mathrm{N}$. The SST seasonal cycle was computed using 1997-2004 data obtained from NOAA's Pacific Fisheries Environmental Laboratory Live Access Server.

Figura 7. Patrón temporal de las capturas de sardina del Pacífico (Sardinops sagax) en las aguas frente al norte de Baja California (1990-2005, línea negra), obtenido de los datos de capturas mensuales de la Subdelegación de Pesca de Ensenada (Baja California, México). Promedios mensuales de la temperatura superficial del mar (SST, línea azul) a $\sim 80 \mathrm{~km}$ de la costa, cerca de $31^{\circ} \mathrm{N}$. El ciclo estacional de la SST se calculó utilizando los datos de 1997 a 2004 obtenidos del Pacific Fisheries Environmental Laboratory Live Access Server de la NOAA.

compleja y tan intrincadamente ligada a factores ambientales y ecológicos, al igual que las causas en la supervivencia de huevos y larvas."

De marzo a junio de 2002 los desembarques de sardina en Ensenada (puerto de El Sauzal) incluyeron individuos juveniles (prereclutas) de menos de $15 \mathrm{~cm}$ de largo (menor que la talla legal), de menos de 1 año de edad y de menos de $50 \mathrm{~g}$ de peso (fig. 5), y sugirieron un patrón de reclutamiento que depende del desove del año previo (febrero a julio de 2001). Se observa un contraste importante en cuanto a tamaño y peso entre el primer y el segundo semestre del año. La predominancia de la subpoblación subtropical de sardina en la captura resultó en un cambio abrupto a una talla mayor en julio (mostrado en fig. 5) y su condición mejoró en julio y agosto en comparación con el primer semestre dominado por individuos de la subpoblación subártica (mostrado en fig. 6). La disminución de la talla de las sardinas entre agosto y noviembre que se aprecia en la figura 5 probablemente fue causada por la pesquería, como lo mencionan Hsieh et al. (2006). 


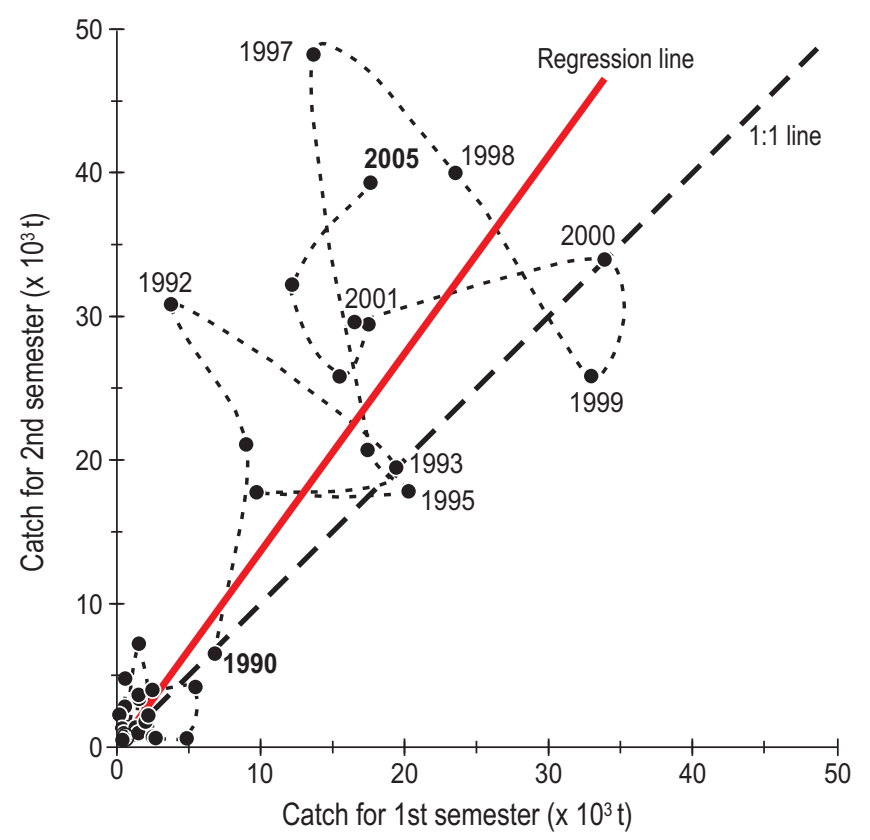

Figure 8. Interannual change in sardine catch rates in temperatecold waters off Ensenada from 1980 to 2005. The red regression line shows the progressive increase in the contribution of the temperate southern stock (July-December). Colder years are shown below the regression line and in relation to the ideal rate (heavy dashed line). The thin dashed line indicates the evolution time of catches.

Figura 8. Cambio interanual en las tasas de captura de sardina en aguas frío-templadas frente a Ensenada de 1980 a 2005. La línea de regresión roja muestra el incremento progresivo de la contribución de la subpoblación asociada con aguas templadas (julio a diciembre). Los años más fríos se muestran debajo de la línea de regresión y con relación a la tasa ideal (línea discontinua gruesa). La línea discontinua delgada indica el tiempo de evolución de las capturas.

from predation and as a source of higher food concentration for the young fish.

Figure 7 shows that the reduced landings of the subarctic stock are associated with minimum temperatures during spring and that the elevated landings of the subtropical stock are associated with higher temperatures in late summer and fall. The ratio of the catches of subarctic stock in the first semester (January-June) to the catches of subtropical stock in the second semester (July-December) indicates that the availability of the subtropical stock to the Ensenada fleet is reduced in cold years, whereas the availability of the subarctic stock is reduced during warm years, as demonstrated by figure 8 for the years between 1980 and 2005. Demer and Zwolinski (2014) reported that the southern subtropical stock represented $60-70 \%$ (from 36,000 to $42,000 \mathrm{t}$ ) of the catch landed at Ensenada in the months from May to November of the years 2006 to 2011. In our opinion there is a small bias in their estimates since this period overlaps the months in which the northern stock is present off Ensenada (May and June, according to our fig. 7).
Los desembarques de la flota pesquera de Ensenada sugieren que la disponibilidad de sardinas depende de los movimientos latitudinales de las subpoblaciones en el SCC. La figura 7 muestra que hay un retraso de uno o dos meses entre los promedios mensuales de la climatología de largo plazo de las capturas y la TSM, lo que indica que la modificación estacional de las condiciones del hábitat induce una migración sincrónica de las subpoblaciones subártica y subtropical en concordancia con el modelo conceptual del movimiento de las subpoblaciones presentada por Félix-Uraga et al. (2004). Esto podría ser una respuesta de la biomasa de ambas subpoblaciones después del movimiento latitudinal de sus hábitats característicos. En verano y otoño, la subpoblación sureña se desplaza hacia el norte hasta San Pedro, California, y se contrae hacia la costa debido al calentamiento estacional. En invierno, la subpoblación norteña se desplaza hacia el sur hasta la parte norte y central de la península de Baja California y enseguida hacia mar adentro para desovar en primavera con el fin de evitar el agua fría de surgencia en la costa; por lo tanto, las capturas para 2002 son menores en abril, mayo y junio, como se muestra en la figura 5. Cabe mencionar que los peces de edad 0 constituyeron alrededor de la mitad de los desembarques durante este periodo (fig. 5). Esto sugiere que la zona cerca de la costa proporciona refugio contra los depredadores y una mayor concentración de alimento para los peces jóvenes.

La figura 7 muestra que los desembarques menores de la subpoblación subártica se asocian con las temperaturas mínimas en primavera y que los desembarques mayores se asocian con las temperaturas más altas a finales de verano y otoño. La proporción entre las capturas de la subpoblación subártica en el primer trimestre (enero a junio) y las capturas de la subpoblación subtropical en el segundo semestre (julio a diciembre) indican que hay menor disponibilidad de la subpoblación subtropical para la flota de Ensenada en años fríos y menor disponibilidad de la subpoblación subártica en años cálidos, como lo muestra la figura 8 para los años entre 1980 y 2005. Demer y Zwolinski (2014) informaron que la subpoblación subtropical representó $60-70 \%$ (de 36,000 a $42,000 \mathrm{t}$ ) de las capturas desembarcadas entre mayo y noviembre de los años de 2006 a 2011. En nuestra opinión, sus estimaciones están ligeramente sesgadas ya que este periodo se traslapa con los meses cuando la subpoblación norteña se encuentra frente a Ensenada (mayo y junio, según nuestra fig. 7).

La falta de diferenciación genética entre la subpoblación subártica y la subpoblación subtropical ha sido difícil de explicar. Nosotros proponemos que durante los periodos de contracción de la subpoblación norteña en las aguas frente a la península de Baja California se mezclan desovadores de ambas subpoblaciones, como sucedió durante el periodo de enfriamiento prolongado que duró unos 30 años, desde finales de la década de 1940 hasta mediados de la década de 1970. Los promedios anuales del índice de la ODP que inician en 1900 claramente muestran este periodo 
The lack of genetic differentiation between the northern subarctic and southern subtropical stocks has been difficult to explain. We propose that the periods of contraction of the northern stock into the waters off Baja California leads to the mixing of spawners from the two stocks, as occurred during the prolonged period of cooling lasting roughly 30 years from the late 1940s through the mid-1970s. The prolonged period of cooling is clearly evident in the annual means of the PDO index beginning in 1900 (available from http:// www.atmos.washington.edu/ mantua/abst.PDO.html).

Ahlstrom (1960) indicated that sardines had disappeared from the region north of Point Conception by 1952 and moved southward into waters off the Baja California Peninsula, mainly between Punta Eugenia in central Baja California and Cabo San Lucas at the tip of the peninsula. According to Rodríguez-Sánchez et al. (2001), juvenile sardines were found inside the Gulf of California in the 1960s. This mixing of the spawners off Baja California would clearly be expected to result in similar genetic composition between the two stocks, and the lack of differentiation would be maintained as the subarctic stock expanded northwards into British Columbia in the early 1990s during the recovery of the population. This is supported by Zaitsev et al. (2014), who reported the presence of subarctic water mixing with subtropical surface water in front of Magdalena Bay from January 2011 to April 2012. The latter in turn agrees with the observation made by Félix-Uraga et al. (2013) at the 2013 meeting of the Trinational Sardine Forum in Ensenada, that fish from the northern stock were present in Magdalena Bay in 2011 and 2012. Their abstract reports "landings of Pacific sardine decreased progressively from 2007 to 2010. Subsequently catches increased in 2011 and 2012, probably because sardines from the northern stock migrated to the south where they joined with sardines of the southern stock. There is evidence that currently the Pacific sardine population in the California Current System is collapsing. When this happens, this resource seeks refuge in the south of its distribution range, and a mixture of northern and southern stocks is likely to occur. Larger and older sardines than usually recorded in Magdalena Bay could be evidence of this migration of northern stock to the southern coast of the Baja California Peninsula".

The sedimentary record of sardine scale deposition in the CCS beginning at approximately $400 \mathrm{AD}$ indicates that the period of expansions and contractions of the sardine population is centered around 60 years (Baumgartner et al. 1992). This suggests that variability in ocean climate provides a mechanism for almost continuous mixing of the two stocks that has apparently prevented any significant genetic differentiation between the stocks since their appearance in the CCS thousands of years ago.

Smith (2005) reviewed the different methods that have been used to distinguish between the sardine stocks in the CCS: tagging (to discern migration histories), vertebral counts, differences in blood types, growth rates (size at age) de enfriamiento (http://www.atmos.washington.edu/ mantua/ abst.PDO.html).

Según Ahlstrom (1960), las sardinas habían desaparecido de la región al norte de punta Concepción en 1952 y se habían desplazado hacia el sur a aguas frente a la península de Baja California, principalmente entre punta Eugenia en la parte central y cabo San Lucas en la punta de la península. Rodríguez-Sánchez et al. (2001) informaron de la presencia de individuos juveniles dentro del golfo de California a principios de la década de 1960. Cabría pensar que debido a esta mezcla de desovadores frente a Baja California la composición genética sería similar, y que la falta de diferenciación se mantendría conforme la subpoblación subártica se desplazó hacia el norte hasta la Columbia Británica a principios de la década de 1990, durante la recuperación de la población. Esto es consistente con los resultados de Zaitsev et al. (2014), quienes observaron la presencia de agua subártica que se mezcló con agua subtropical superficial frente a bahía Magdalena de enero de 2011 a abril de 2012. De igual manera, en la reunión del Foro Trinacional de la Sardina realizada en Ensenada en 2013, Félix-Uraga et al. (2013) informaron que peces de la subpoblación del norte estuvieron presentes en la bahía Magdalena en 2011 y 2012. Según su resumen, "Los desembarques de sardina del Pacífico disminuyeron progresivamente de 2007 a 2010. Las capturas subsecuentes aumentaron en 2011 y 2012, probablemente porque las sardinas de la subpoblación norteña migraron hacia el sur donde se juntaron con las sardinas de la subpoblación sureña. Hay evidencia de que actualmente se está colapsando la población de sardina del Pacífico en el Sistema de la Corriente de California. Cuando esto sucede, este recurso busca refugio al sur de su rango de distribución, y es probable que se produzca una mezcla de las subpoblaciones norteña y sureña. Sardinas de mayor tamaño y edad que normalmente se registran en la bahía Magdalena podrían ser evidencia de esta migración de la población del norte a la costa sur de la península de Baja California".

El registro sedimentario de la deposición de escamas de sardina que inició en aproximadamente $400 \mathrm{AD}$ indica que el periodo de expansiones y contracciones de la población de sardina es de alrededor de 60 años (Baumgartner et al. 1992). Esto sugiere que una variación del clima oceánico proporciona un mecanismo para la mezcla casi continua de las dos subpoblaciones, que al parecer ha impedido una diferenciación genética importante entre ellas desde su aparición en el SCC hace miles de años.

Smith (2005) realizó una revisión de los diferentes métodos que se han usado para distinguir las subpoblaciones de sardina en el SCC: marcaje (para discernir las historias de migración), conteo de vértebras, diferencias en los tipos de sangre, tasas de crecimiento (tamaño a cierta edad) y de mortalidad natural, y el tiempo y lugar de reclutamiento. Este autor sugirió usar el cambio en el número de vértebras para indicar el crecimiento larval y la temperatura en el sitio de desove. Smith también sugirió usar la microquímica e 
and natural mortality rates, and the timing and location of recruitment. This author suggested using the change in number of vertebrae to indicate larval growth and temperature at the spawning site. Smith also suggested exploring the use of microchemistry and stable isotopes in otoliths of post-larval sardines to determine the composition and temperature of water at spawning locations in the Gulf of California and in the CCS (Valle-Rubio 2007). Smith (2005) identified three stocks by names that reflect their spawning areas: the Gulf of California, the inshore region off the southern Baja California Peninsula (our southern, subtropical stock), and the central California offshore region (our northern, subarctic stock). As we know, the offshore California stock and the inshore stock of Baja California overlap but do not mix and thus do not spawn together in "normal" years in the region between San Pedro (the fishing port in southern California) and Ensenada (the fishing port in northern Baja California).

Parrish et al. (1989) discuss the level of taxonomic separation between sardines from different ecosystems and emphasize that the level of genetic difference among subpopulations (stocks) in the same region is expected to be negligible relative to the time needed to acquire more significant differences over evolutionary time scales for geographicallyand, therefore, reproductively-isolated populations, resulting in distinctive phenotypes with adaptation and genetic drift. It is possible for an isolated population to maintain its genetic identity but, under changing environmental conditions, it would develop a completely different life history. Thus, it is reasonable to expect that subpopulations may be distinguished by their morphometric and meristic differences even though, according to Stepien and Rosenblatt (1996) in their study of Pacific and jack mackerel, there is no detectable genetic difference.

Since sardine fishing preferentially removes adults, the population will eventually be comprised of more juveniles (Hsieh et al. 2006). Juvenile sardines are more susceptible than adults to changes in their environment brought on by variability in ocean climate. Anderson et al. (2008) did not find robust evidence of the fishing impact relative to juveniles in the population. However, year classes associated with the recruitment may reflect their greater presence in the fisheries (Zwolinski and Demer 2013). Similarly, observations by Hsieh et al. (2006) report a significant reduction in the average age of the sardine fishery in California in the period 1983-2004 that may be associated with the expansion of the subtropical stock. The greater presence of juveniles in the first semester catch off Ensenada may be the cause of the higher correlation with the PDO during the period 1997-2005 (fig. 9). Fishing should actually produce homogenization of sizes since there will be fewer adults in the population. Thus, the subtropical stock is probably responsible for the strong correlation between the PDO and the ratio of second semester landings to first semester landings $\left(R^{2}=0.8\right.$ during 1997-2005), compared to the lack of correlation in the earlier phase of the fishery development (1990-1996), when isótopos estables en otolitos de postlarvas de sardinas para determinar la composición y temperatura del agua de los sitios de desove en el golfo de California y en el SCC (ValleRubio 2007). Smith (2005) identificó tres subpoblaciones con nombres que reflejan sus áreas de desove: el golfo de California, la zona costera del sur de la península de Baja California (nuestra subpoblación subtropical sureña), y la región alejada de la costa frente a la parte central de California. Como se sabe, la subpoblación alejada de la costa de California y la subpoblación en la costa del sur de la península de Baja California se traslapan, pero no se mezclan ni desovan juntas en años "normales" en la región entre San Pedro (puerto de pesca en el sur de California) y Ensenada (puerto de pesca en el norte de Baja California).

Parrish et al. (1989) discuten sobre el nivel de separación taxonómica entre sardinas de diferentes ecosistemas y enfatizan que el nivel de diferencia genética entre subpoblaciones en la misma región debería ser despreciable en relación con el tiempo que se necesita para adquirir diferencias más importantes en escalas de tiempo evolutivo para poblaciones aisladas geográficamente y, consecuentemente, reproductivamente, lo cual resulta en fenotipos distintivos con adaptación y deriva genética. Una población aislada podría mantener su identidad genética, pero en condiciones ambientales cambiantes, desarrollaría una historia de vida completamente diferente. Por lo tanto, es razonable pensar que las subpoblaciones se pueden distinguir por sus diferencias morfométricas y merísticas aun cuando, según Stepien y Rosenblatt (1996) en su estudio de S. japonicus y T. symmetricus, no hay una deferencia genética detectable.

La pesquería de sardina preferentemente captura adultos, por lo que la población eventualmente consistirá de un mayor número de juveniles (Hsieh et al. 2006). Los individuos juveniles son más susceptibles que los adultos a cambios en su ambiente derivados de la variabilidad del clima oceánico. Anderson et al. (2008) no encontraron evidencia robusta del efecto de la pesca en los juveniles de la población. No obstante, las clases anuales asociadas con el reclutamiento pueden reflejar su mayor presencia en las pesquerías (Zwolinski y Demer 2013). Según Hsieh et al. (2006), la edad promedio en la pesquería de sardina de California disminuyó considerablemente durante el periodo de 1983 a 2004, posiblemente debido a la expansión de la subpoblación subtropical. La mayor presencia de individuos juveniles en la captura de Ensenada durante el primer semestre del año podría ser la causa de la mayor correlación con la ODP durante el periodo de 1997 a 2005 (fig. 9). La pesca debería homogeneizar las tallas ya que habrá menos adultos en la población. Por lo tanto, la población subtropical probablemente es responsable de la fuerte correlación entre la ODP y la proporción de las capturas del segundo semestre en relación al primero $\left(R^{2}=0.8\right.$ de 1997 a 2005), en comparación con la falta de correlación en la fase previa del desarrollo de la pesquería (1990 a 1996), cuando la subpoblación norteña (durante su recuperación) dominó la pesquería de Ensenada 


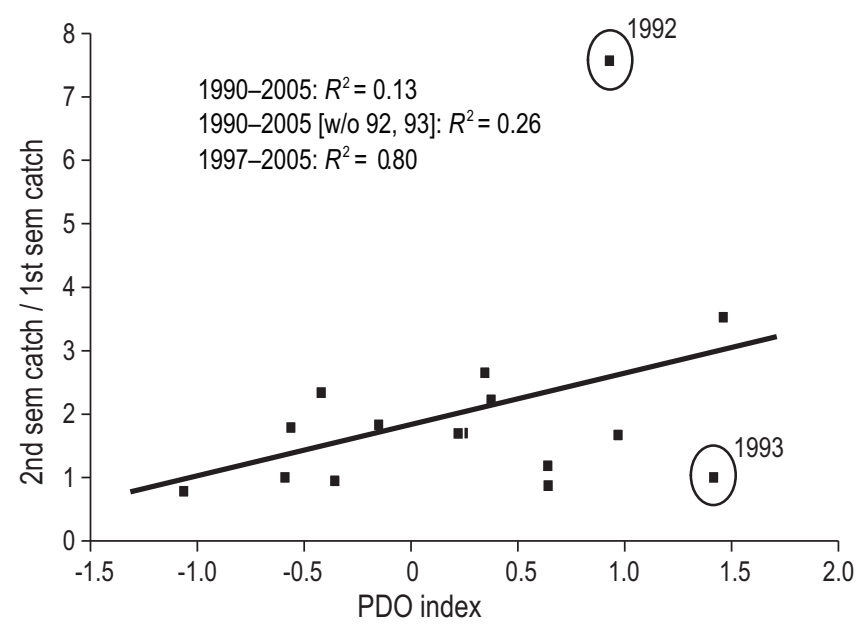

Figure 9. Ratio between second and first semester catches off Ensenada in relation to the Pacific Decadal Oscillation (PDO) index. The least-squares regression line $\left(R^{2}=0.80\right)$ is given for the period 1990-2005.

Figura 9. Proporción de las capturas del segundo y primer semestre frente a Ensenada con relación al índice de la Oscilación Decadal del Pacífico (PDO). Se muestra la línea de regresión de mínimos cuadrados $\left(R^{2}=0.80\right)$ para los datos del periodo de 1990 a 2005.

the northern stock (during its recovery) dominated the Ensenada fishery except for the year prior to the $1992 \mathrm{El}$ Niño (fig. 8). During 2006-2010, the southern stock continuously dominated the catch off Ensenada. Landings of the subarctic stock during this period ranged from $22 \%(12,540 \mathrm{t}$ in $2006)$ to $51 \%(18,771 \mathrm{t}$ in 2007$)$ of the total annual catch (Demer and Zwolinski 2014).

The northern stocks of sardine and mackerel that live in low-salinity and cooler subarctic waters appeared to be declining during the ongoing cold regime that began in 1998 (Lo et al. 2010a, Weber and McClatchie 2012, Zwolinski and Demer 2012). This decline is associated with the intensification of offshore Ekman transport (Bjorkstedt et al. 2010). The regional cooling in surface temperature and the increase in offshore transport has resulted in a southward shift in biomass and more offshore transport of eggs and larvae, while the effects of the increased dispersion have actually decreased the concentrations of food available, limiting the size of annual year classes that are recruited to the adult population. This response was also observed during the cooling period that began in the late 1940s, pushing the remnants of both the sardine and Pacific mackerel biomass southward into the waters off northern Baja California, a region that is essentially a desert relative to the availability of food in the region off southern and central California (fig. 11 in Lo et al. 2005, Baumgartner et al. 2008). This scarcity of food apparently was the cause of the reproductive failures (Marr 1960) during each year until their combined biomasses had dwindled to a very small fraction, around 6000 t by 1963 excepto durante el año previo a El Niño de 1992 (fig. 8). Entre 2006 y 2010, la subpoblación sureña dominó la captura de Ensenada. Los desembarques de la subpoblación subártica durante este periodo fueron de $22 \%$ (12,540 t en 2006) a $51 \%$ $(18,771 \mathrm{t}$ en 2007) de la captura total anual (Demer y Zwolinski 2014).

Las subpoblaciones norteñas de sardina y macarela que habitan aguas subárticas más frías y de baja salinidad parecen estar disminuyendo durante el presente régimen frío que comenzó en 1998 (Lo et al. 2010a, Weber y McClatchie 2012, Zwolinski y Demer 2012). Este declive está asociado con la intensificación del transporte de Ekman (Bjorkstedt et al. 2010). El enfriamiento regional de la temperatura superficial y el aumento del transporte hacia fuera de la costa ha generado un desplazamiento de la biomasa hacia el sur y una mayor dispersión de huevos y larvas hacia fuera de la costa, mientras que los efectos de esta mayor dispersión han disminuido las concentraciones de alimento disponible, lo que limita el tamaño de las clases de edad reclutadas anualmente a la población adulta. Esta respuesta también fue observada durante el periodo de enfriamiento que comenzó a finales de la década de 1940. La biomasa restante tanto de la sardina como la macarela del Pacífico fue empujada hacia el sur a aguas frente al norte de la península de Baja California, una región que es esencialmente un desierto en relación con la disponibilidad de alimento en la región frente al sur y centro de California (fig. 11 en Lo et al. 2005, Baumgartner et al. 2008). Esta carencia de alimento aparentemente fue la causa de fracasos reproductivos (Marr 1960) año tras año hasta que su biomasa combinada había disminuido a una fracción muy pequeña, alrededor de 6000 t en 1963 (MacCall 1979). En nuestra opinión, durante el periodo actual se podría desarrollar una situación similar a la ocurrida para ambas especies en las décadas de 1950 y 1960. Esta tendencia también se observa en la reducción de la densidad de huevos de sardina $\left(<50\right.$ huevos $\left.\mathrm{m}^{-3}\right)$ observada de 2010 a 2013 en la región central y sur de California, donde las temperaturas varían de 13 a $15^{\circ} \mathrm{C}$ (http://swfsc.noaa.gov/).

Los indicadores climáticos sugieren que la subpoblación subártica debería ser la subpoblación de sardina dominante durante el actual periodo de enfriamiento que comenzó en 1998. No obstante, los desembarques en el sur de California y Baja California indican que la subpoblación dominante es la subtropical mientras que la subártica aparentemente se localiza al sur de punta Eugenia. La razón de esta inesperada dominancia de la subpoblación subtropical en el norte de la península de Baja California durante este periodo de enfriamiento aún no es clara. Un efecto es que ha bajado la fecundidad debido al menor tamaño de los individuos. Lo que sí es claro, sin embargo, es la necesidad de que México y los Estados Unidos realicen monitoreos conjuntos que puedan mejorar nuestro entendimiento de la respuesta de las especies al forzamiento ambiental, conocimiento que nos permitiría lograr pesquerías sustentables de peces pelágicos menores 
(MacCall 1979). We believe that a similar situation may develop during the current period for both species as occurred during the 1950s and 1960s. This tendency is also found in the reduction in sardine egg density $\left(<50\right.$ eggs $\left.\mathrm{m}^{-3}\right)$ observed from 2010 to 2013 in the region of central and southern California where temperatures range from 13 to $15^{\circ} \mathrm{C}$ (http://swfsc.noaa.gov/).

Climatic indicators suggest that the northern subarctic stock should be the dominant sardine stock during this ongoing cold period that began in 1998. However, landings along southern California and Baja California indicate the dominance of the subtropical southern stock while the northern subarctic stock is apparently located south of Punta Eugenia. The reason is not yet clear for this unexpected dominance of the subtropical stock in northern Baja California during this cooling period. One effect is that it has lowered fecundity because of the smaller sizes of individuals. What is clear, however, is the need for collaborative monitoring between Mexico and the United States that would improve our understanding of the response to environmental forcing and would allow us to achieve the sustainable fisheries of our common small pelagic resources that we desire and are needed to insure the health of the $\mathrm{CC}$ ecosystem.

The study of the dynamics of the anchovy and sardine populations is based on different techniques that recognize at least a degree of structure using genetic (for anchovy) plus morphometric and meristic characteristics, as well as the location and area of their spawning grounds. Commercial catches in Baja California are generally taken near the coast, within a strip approximately $20 \mathrm{~km}$ offshore, and stock discrimination is based on SST that could be improved by also including sea surface salinity as shown in figure 3 . While discrimination allows for the generation of relevant time series between ocean climate and distribution and, therefore, the availability of the resource in space and time, it does not provide any information on stock abundance. There is a need for an objective, independent assessment of fish population abundances in near real-time which is now one of the features of the management plan that will cover the actively managed stocks. This will allow the fishing fleet to function more efficiently with the timing and location of the target resource that should result in savings of both time and operational costs.

Our experience with the use of the CUFES system on the IMECOCAL research cruises has shown that it provides high resolution of the distribution and abundance of near-surface eggs along the ship tracks and an indirect means for estimating the biomass of the small pelagic species found within the samples. Although the method is restricted to sampling in the upper $3-5 \mathrm{~m}$ of the water column, there is ample coverage over the survey region with ship tracks extending $\sim 220 \mathrm{~km}$ offshore. We assume that the abundance of eggs collected represents the mean abundance of a 5-km strip on either side of the ship track. On our small research vessel (the Ulloa) we were not able to implement "adaptive sampling", meaning that we could not stop the ship once we identified an area que tenemos en común y que son necesarios para asegurar la salud del ecosistema de la CC.

El estudio de la dinámica de las poblaciones de anchoveta y sardina se realiza con diferentes técnicas que reconocen al menos un grado de estructura y que usan características tanto genéticas (para la anchoveta) como morfométricas y merísticas, además de la ubicación y tamaño de sus sitios de desove. En Baja California, las capturas comerciales generalmente se realizan cerca de la costa, dentro de una franja de $20 \mathrm{~km}$, y la discriminación de las subpoblaciones se realiza en relación con la TSM, y podría mejorar si se considera también la salinidad superficial del mar, como se muestra en la figura 3. La discriminación permite generar series de tiempo relevantes entre el clima del océano y la distribución y, por lo tanto, la disponibilidad del recurso en el espacio y el tiempo, pero no proporciona información de la abundancia de la subpoblación. Se requiere una evaluación objetiva e independiente de la pesquería para la estimación de la abundancia de las poblaciones de peces en tiempo real, lo cual está ahora incorporado en el plan de manejo que cubrirá las especies con manejo activo de su pesquería. Esto permitirá que la flota pesquera opere con mayor eficiencia en cuanto al tiempo y el lugar de búsqueda del recurso, con un ahorro de tiempo y costos operacionales.

Nuestra experiencia con el uso del sistema CUFES en los cruceros del programa IMECOCAL nos ha mostrado que este sistema proporciona una alta resolución de la distribución y abundancia de huevos recolectados cerca de la superficie a lo largo de la ruta del barco, así como una forma indirecta para estimar la biomasa de los peces pelágicos menores que se encuentran en las muestras. A pesar de que sólo se puede muestrear en los primeros 3 a $5 \mathrm{~m}$ de la columna de agua, la cobertura en la región de estudio es amplia y se extiende hasta $\sim 220 \mathrm{~km}$ de la costa. Se supone que la abundancia de los huevos recolectados representa la abundancia promedio de una franja de $5 \mathrm{~km}$ a cada lado de la línea de navegación del barco. Con el pequeño buque oceanográfico (el Ulloa) usado anteriormente no era posible implementar un "muestreo adaptativo". Esto significa que no era posible parar el barco cuando se identificaba una zona con abundantes huevos para lanzar, hasta $70 \mathrm{~m}$ de profundidad, una pequeña red (CalVET) que se usa para recolectar huevos en la capa de mezcla. Con la nueva embarcación de $49 \mathrm{~m}$ será posible examinar cada muestra en tiempo real para identificar las que tienen un umbral de $>10$ huevos en 30 min de bombeo.

Otra desventaja importante del diseño del muestreo actual del programa IMECOCAL es que las líneas hidrográficas están separadas por una distancia de $74 \mathrm{~km} \mathrm{y}$, según el teorema de Nyquist (Kelly 1976), sólo se pueden identificar zonas de desove que se extienden una distancia mayor que $148 \mathrm{~km}$ entre las líneas de muestreo (en dirección paralela a la costa). Por lo tanto, la distancia entre las líneas se tendría que reducir a menos de $37 \mathrm{~km}$. El diseño del muestreo requiere de por lo menos cuatro cruceros al año para obtener una idea estacional (enero, abril, julio y octubre) del estado 
with abundant eggs in order to make a vertical cast down to $70 \mathrm{~m}$ of a small net (CalVET) used to collect eggs within the mixed layer. In our new 49-m vessel it will be possible to scan each sample in real time to identify samples with a threshold of $>10$ eggs for 30 min of pumping.

Another important drawback of the current survey design is that the IMECOCAL tracklines are separated by a distance of $74 \mathrm{~km}$ and, according to the Nyquist theorem (Kelly 1976), we can only identify areas of spawning between tracklines (in the alongshore direction) that extend for distances greater than $148 \mathrm{~km}$. Therefore, the distance between the tracklines would need to be reduced to less than $37 \mathrm{~km}$. The survey design calls for four cruises a year to provide a seasonal picture of the annual state of the ecosystem (January, April, July, and October) that will allow us to determine the distribution and abundance as well as the seasonal change in character of the spawning habitat. A further disadvantage is that we only obtained information over a two- to three-week period on each of the quarterly cruises and thus can only infer what goes on between the cruises. The cost of ship time makes more frequent sampling prohibitive. The only alternative would be to run monthly lines in selected areas in small boats and this would mean trading time for distance. Moreover, our vessel is not currently equipped with hydroacoustics to locate and estimate fish biomass, nor do we have proper trawling gear to obtain samples for identification and to obtain the adult parameters necessary for the biomass estimation. We thus have to use fish from commercial catches, but since the fleet operates so close to shore we cannot obtain samples of the larger adults offshore, at least in April, which is the peak spawning period of the subarctic stock. We intend to remedy this situation by obtaining the hydroacoustics and fishing gear, but will likely require up to four or five years to obtain financing to purchase and instal the equipment on our vessel.

Morphometric characteristics and distribution of spawning areas of sardine and anchovy stocks are evidence of adaption to specific environmental conditions. This depends mainly on food availability to cover the energetic demands of a population and partitions the CCS into regional habitats, in which each stock prefers a particular size and type of prey. Individuals of a stock use their excess energy for growth and reproduction. Reproductive peaks reflect a seasonal variability in environment conditions in which reproductive strategies are suited to their habitat. Anchovy with oval eggs that lack an oil globule spawn in areas of greater turbulence, whereas sardine with spherical, oil-rich eggs spawn in more stratified conditions outside the upwelling front. These environmental conditions appear to be responsible for the development of the phenotypic characteristics of the two sardine stocks. The genetic differentiation in anchovies is likely the result of their limited migration, in contrast with the lack of genetic differentiation in sardines that can be explained by their more highly migratory behavior that maintains this genetic homogenization. In the case of sardines, unfavorable anual del ecosistema y poder determinar la distribución y abundancia, así como el cambio estacional en la condición del hábitat de desove. Esto significa que solamente se obtiene información para un periodo de dos a tres semanas en cada crucero y lo que sucede entre los cruceros sólo se puede inferir, puesto que no es factible realizar muestreos con mayor frecuencia debido al costo relacionado con el tiempo del barco. La única alternativa sería realizar en zonas seleccionadas recorridos mensuales con embarcaciones pequeñas a lo largo de líneas, lo cual equivale a intercambiar tiempo por distancia. Además, actualmente la embarcación no cuenta con equipo hidroacústico para localizar y estimar la biomasa de peces. Tampoco cuenta con sistemas de pesca de arrastre para obtener muestras para su identificación y para determinar los parámetros de la población adulta a fin de estimar la biomasa, por lo que es necesario usar peces de las capturas comerciales; sin embargo, como la flota opera tan cerca de la costa, no es posible obtener muestras de individuos adultos alejados de la costa, especialmente en abril, que es el periodo de máxima actividad reproductiva de la subpoblación subártica. Se espera que esta situación cambie en unos cuatro o cinco años con la adquisición e instalación de equipo hidroacústico y artes de pesca.

Las características morfométricas y la distribución de las zonas de desove de las subpoblaciones de sardina y anchoveta son evidencia de la adaptación a condiciones ambientales específicas. Esto depende principalmente de la disponibilidad de alimento para cubrir la demanda energética de una población y divide el SCC en hábitats regionales, en los cuales cada subpoblación prefiere un tipo de presa de cierto tamaño. Los individuos de una población usan el exceso de energía para crecimiento y reproducción. Los periodos de máxima actividad reproductiva reflejan una variabilidad estacional de las condiciones ambientales en las cuales las estrategias de reproducción son apropiadas al hábitat. Las anchovetas, que tienen huevos ovalados que carecen de un glóbulo de aceite, desovan en zonas de mayor turbulencia, mientras que las sardinas, que tienen huevos esféricos y ricos en aceite, desovan en condiciones más estratificadas fuera del frente de surgencia. Estas condiciones ambientales parecen ser responsables del desarrollo de las características fenotípicas de las dos subpoblaciones de sardina. La diferenciación genética de las anchovetas probablemente sea resultado de su migración limitada, en contraste con la diferenciación genética de las sardinas cuya mayor migración mantiene esta homogeneización genética. En el caso de las sardinas, las condiciones ambientales desfavorables conducen a un menor reclutamiento y la mezcla de ambas subpoblaciones en los centros de refugio frente a la península de Baja California.

En resumen, el objetivo de esta revisión fue proveer un marco teórico para describir los mecanismos y procesos que alteran el hábitat oceánico y los rasgos de la historia de vida, y que estructuran la población de peces pelágicos menores. Esto incluye una descripción del escenario físico del 
environmental conditions lead to decreased recruitment and mixing of both stocks in the refuge centers off the Baja California Peninsula.

In summary, the objective of this review has been to provide a framework to describe the mechanisms and processes that alter ocean habitat and life history traits, and that structure the population of small pelagic fishes. This includes a description of the physical setting of the environment occupied by these species, their life cycles, and distribution patterns in the southern reaches of the CC ecosystem. We used a historical perspective to examine the relationship between landings and availability of fish to explain how the movements of these resources are sensitive to climate variability and thus determine when and where they are captured. This is done to illustrate the idea that climate determines the success or failure of the fishery through the availability of the resource. We have presented more complete descriptions of the behavior and character of only three of the four species of small pelagic fishes and their interaction with the ocean climate of the CCS. The relatively small amount of information on $T$. symmetricus has limited our description to include only distribution of habitat and that presented in tables 1 to 3 .

Environmental forcing associated with the regional wind field is largely responsible for the structure and maintenance of the condition of the spawning habitats and food availability. Habitat conditions depend on the variability of the different time and spatial scales that influence productivity and recruitment of a population. Monitoring the state of the ecosystem requires the development of tools that permit us to evaluate its productivity in relation to the environmental conditions, in combination with the effects of fishing. The goal is to construct time series of environmental variables that control the size and reproductive potential of the annual year classes of the fishery stocks. In order to explain the lack of genetic differentiation between the subarctic and subtropical stocks, we have proposed that the mixing and incorporation of individuals from the subtropical stock into the subarctic stock will result in the recruitment of juveniles from the subtropical stock into the subarctic stock and vice versa so that genetic mixing is complete by the time their respective migrations are underway. It is important to emphasize that determining the patterns of movement of stocks and the areas where their overlap is critical to achieving sustainable fisheries.

\section{ACKNOWLEDGMENTS}

This study was supported by the IMECOCAL program through the National Council for Science and Technology (CONACYT, Mexico; research initiatives no. 129140, 99252, 23947, 47044, 42569, G35326T, 017P\D1-1297, G0041T, and 23804. Numerical model output data were made available by the Asia-Pacific Data-Research Center of the IPRC (http://apdrc.soest.hawaii.edu). The lead author acknowledges receipt of a CONACYT PhD scholarship ambiente que ocupan estas especies, sus ciclos de vida y patrones de distribución en el extremo sur del ecosistema de la CC. Se utilizó una perspectiva histórica para examinar la relación entre las capturas y la disponibilidad de peces para explicar cómo los movimientos de estos peces sensibles a la variabilidad climática determinan cuándo y dónde son capturados, con el fin de ilustrar que el clima determina el éxito o fracaso de una pesquería a través de la disponibilidad del recurso. Hemos presentado descripciones más completas del comportamiento y carácter de tres de las cuatro especies de peces pelágicos menores y su interacción con el clima oceánico del SCC. La poca información sobre T. symmetricus permitió describir la distribución del hábitat y lo que se presenta en las tablas 1 a 3 .

El forzamiento ambiental asociado al campo de viento regional es responsable, en gran medida, de la estructura y el mantenimiento de la condición de los hábitats de desove y de la disponibilidad de alimento. La variabilidad climática, en las diferentes escalas temporales y espaciales, modifica la condición del hábitat y afecta la productividad y el reclutamiento de una población. Para monitorear el estado de un ecosistema es necesario desarrollar herramientas que permitan evaluar su productividad en relación a las condiciones ambientales y los efectos de la pesca. El objetivo es construir series de tiempo de las variables ambientales que controlan el tamaño y potencial reproductivo de las clases anuales de las poblaciones pesqueras. Para explicar la falta de diferenciación genética entre las subpoblaciones subártica y subtropical, hemos propuesto que la mezcla e incorporación de individuos de la subpoblación subtropical a la subpoblación subártica resultará en el reclutamiento de juveniles de la subpoblación subtropical a la subpoblación subártica y viceversa, de tal manera que la mezcla genética se haya completado para cuando se estén realizando sus respectivas migraciones. Es importante enfatizar que la determinación de los patrones de movimiento de las subpoblaciones y de las zona de traslape son fundamentales para lograr la sustentabilidad de las pesquerías.

\section{Agradecimientos}

Este estudio fue apoyado por el programa IMECOCAL a través del Consejo Nacional de Ciencia y Tecnología (CONACYT, México; proyectos no. 129140, 99252, 23947, 47044, 42569, G35326T, 017P\D1-1297, G0041T у 23804). El Asia-Pacific Data-Research Center del IPRC (http:// apdrc.soest.hawaii.edu) proporcionó los datos de salida del modelo numérico. El primer autor agradece la beca de doctorado otorgada por el CONACYT (269626), así como el apoyo de la UABC. Ed Weber (Southwest Fisheries Science Center) hizo sugerencias valiosas que mejoraron el manuscrito. Los comentarios y sugerencias realizadas por tres revisores anónimos mejoraron sustancialmente este trabajo.

Traducido al español por Christine Harris. 
(269626), as well as support from UABC. Ed Weber (Southwest Fisheries Science Center) made valuable suggestions that greatly improved this manuscript. Comments and suggestions made by the three anonymous reviewers greatly improved this manuscript.

\section{REFERENCES}

Ahlstrom EH. 1954. Pacific Sardine (Pilchard) Eggs and Larvae and Other Fish Larvae, Pacific Coast - 1952. US Department of the Interior, Fish and Wildlife Service, Washington, DC, 76 pp.

Ahlstrom EH. 1960. Fish spawning in 1957 and 1958. CalCOFI Rep. 7: 173-179.

Ahlstrom EH. 1966. Distribution and Abundance of Sardine and Anchovy Larvae in the California Current Region off California and Baja California, 1951-64: A Summary. Special Scientific Report-Fisheries (534), U.S. Fish and Wildlife Service, Washington, D.C., 71 pp.

Ahlstrom EH, Ball OP. 1954. Description of eggs and larvae of jack mackerel (Trachurus symmetricus) and distribution and abundance of larvae in 1950 and 1951. Fish. Bull. 56: 207-245.

Alheit J, Roy C, Kifani S. 2009. Decadal-scale variability in populations. In: Checkley D, Alheit J, Oozeki Y, Roy C (eds.), Climate Change and Small Pelagic Fish. Cambridge University Press, Cambridge, UK, pp. 64-87.

Anderson CNK, Hsieh C, Sandin SA, Hewitt R, Hollowed A, Beddington J, May RM, Sugihara G. 2008. Why fishing magnifies fluctuations in fish abundance. Nature 452: 835-839.

Bakun A, Broad K. 2002. Climate and Fisheries: Interacting Paradigms, Scales, and Policy Approaches. The IRI-IPRC Pacific Climate-Fisheries Workshop, Honolulu, 14-17 November 2001. International Research Institute for Climate Prediction (IRI), $66 \mathrm{pp}$.

Barange M, Bernal M, Cergole MC, Cubillos LA, Daskalov GM, de Moor CL, de Oliveira JAA, Dickey-Collas M, Gaughan DJ, Hill K, Jacobson LD, Köster FW, Massé J, Ñiquen M, Nishida H, Oozeki Y, Palomera I, Saccardo SA, Santojanni A, Serra R, Somarakis S, Stratoudakis Y, Lingen CD, Uriarte A Van der, Yatsu A. 2009. Current trends in the assessment and management of stocks. In: Checkley DM, Roy C, Oozeki Y, Alheit J (eds.), Climate Change and Small Pelagic Fish. Cambridge University Press, Cambridge, UK, pp. 191-255.

Barth JA, Pierce SD, Smith RL. 2000. A separating coastal upwelling jet at Cape Blanco, Oregon and its connection to the California Current System. Deep-Sea Res. II 47: 783-810.

Baumgartner TR, Soutar A, Ferreira-Bartrina V. 1992. Reconstruction of the history of Pacific sardine and northern anchovy populations over the past two millennia from sediments of the Santa Barbara Basin, California. CalCOF1 Rep. 33: $24-40$.

Baumgartner TR, Durazo R, Lavaniegos B, Gaxiola G, Gómez J, García J. 2008. Ten years of change from IMECOCAL observations in the southern region of the California Current Ecosystem. GLOBEC Int. Newslett. 14: 43-54.

Bjorkstedt E, Goericke R, McClatchie S, Weber E, Watson W, Lo N, Peterson B, Emmett B, Peterson J, Durazo R, Gaxiola-Castro G, Chavez F, Pennington JT, Collins CA, Field J, Ralston S, Sakuma K, Bograd SJ, Schwing FB, Xue Y, Sydeman WJ, Thompson SA, Santora JA, Largier J, Halle C, Morgan S, Kim S, Merkens K, Hildebrand JA, Munger LM. 2010. State of the California Current 2009-2010: Regional variation persists through transition from La Niña to El Niño (and back?). CalCOFI Rep. 51: 1-31.
Blaxter JHS, Hunter JR. 1982. The Biology of the Clupeoid Fishes. Academic Press, New York, NY, 398 pp.

Butler JL, Smith PE, Chyan-Hueilo N. 1993. The effect of natural variability of life-history parameters on anchovy and sardine population growth. CalCOFI Rep. 34: 104-111.

[CalCOFI] California Cooperative Oceanic Fisheries Investigations. 1953. California Cooperative Oceanic Fisheries Investigations, Progress Report, 1 July 1952 to 30 June 1953. Sacramento, CA, $44 \mathrm{pp}$.

Carton JA, Giese BS, Grodsky SA. 2005. Sea level rise and the warming of the oceans in the Simple Ocean Data Assimilation (SODA) ocean reanalysis. J. Geophys. Res. (Oceans) 110: 1-8.

Checkley DMJ, Barth JA. 2009. Patterns and processes in the California Current System. Prog. Oceanogr. 83: 49-64.

Checkley Jr DM, Dotson RC, Griffith DA. 2000. Continuous, underway sampling of eggs of Pacific sardine (Sardinops sagax) and northern anchovy (Engraulis mordax) in spring 1996 and 1997 off southern and central California. Deep-Sea Res. II 47: 1139-1155.

Checkley DMJ, Ayon P, Baumgartner T, Bernal M, Coetzee JC, Emmett R, Guevara-Carrasco R, Hutchings L, Ibaibarriaga L, Nakata H, Oozeki Y, Planque B, Schweigert J, Stratoudakis Y, Van der Lingen CD. 2009. Habitats. In: Checkley D, Alheit J, Oozeki Y, Roy C (eds.), Climate Change and Small Pelagic Fish. Cambridge University Press, Cambridge, UK, pp. 12-44.

Clark FN. 1945. Results of tagging experiments in California waters on the sardine (Sardinops caerulea). Fish. Bull. 61: 1-93.

Cota-Villavicencio A, Troncoso-Gaytán R, Romero-Martínez M, Nevárez-Martínez MO. 2010. Situación de la pesquería de pelágicos menores en la costa noroccidental de Baja California durante las temporadas de pesca 2007 y 2008. Cienc. Pesq. 18: 19-32.

Csirke J. 1985. Informe del grupo de trabajo sobre implicaciones e interacciones de la ordenación de la pesca. In: Csirke J, Sharp GD (eds.), Informes de la consulta de expertos para examinar los cambios en la abundancia y composición por especies de recursos neríticos. Food and Agriculture Organization of the United Nations, Fisheries Report no. 291, Vol. 1, Rome.

Demer DA, Zwolinski JP. 2014. Corroboration and refinement of a method for differentiating landings from two stocks of Pacific sardine (Sardinops sagax) in the California Current. ICES J. Mar. Sci. 71: 328-335.

Demer DA, Zwolinski JP, Byers KA, Cutter GR, Renfree JS, Sessions TS, Macewicz BJ. 2012. Prediction and confirmation of seasonal migration of Pacific sardine (Sardinops sagax) in the California Current Ecosystem. Fish. Bull. 110: 52-70.

Di Lorenzo E, Schneider N, Cobb KM, Franks PJ, Chhak K, Miller AJ, McWilliams JC, Bograd SJ, Arango H, Curchitser E, Powell TM, Riviere P. 2008. North Pacific Gyre oscillation links ocean climate and ecosystem change. Geophys. Res. Lett. 35: L08607

Di Lorenzo E, Cobb KM, Furtado JC, Schneider N, Anderson BT, Bracco A, Alexander M, Vimont DJ. 2010. Central Pacific El Niño and decadal climate change in the North Pacific Ocean. Nat. Geosci. 3: 762-765.

Di Lorenzo E, Combes V, Keister JE, Strub PT, Thomas AC, Franks PJS, Ohman MD, Furtado JC, Bracco A, Bograd SJ, Peterson WT, Schwing FB, Chiba S, Taguchi B, Hormazabal S, Parada C. 2013. Synthesis of Pacific Ocean climate and ecosystem dynamics. Oceanography 26: 68-81.

Díaz-Viloria N, Sánchez-Velasco L, Pérez-Enríquez R. 2012. Recent population expansion in the evolutionary history of the Californian anchovy Engraulis mordax. Hidrobiológica 22: 258-266. 
Dickerson TL, Macewicz BJ, Hunter JR. 1992. Spawning frequency and batch fecundity of Chub mackerel, Scomber japonicus, during 1985. CalCOFI Rep. 33: 130-140.

[DOF] Diario Oficial de la Federación. 1993. Norma Oficial Mexicana 003-PESC-1993, para regular el aprovechamiento de las especies de sardina monterrey, piña, crinuda, bocona, japonesa y de las especies anchoveta y macarela, con embarcaciones de cerco, en aguas de jurisdicción federal del océano. DOF, Mexico, DF, 4 pp.

Durazo R. 2009. Climate and upper ocean variability off Baja California, Mexico: 1997-2008. Prog. Oceanogr. 83: 361-368.

Durazo R. 2015. Seasonality of the transitional region of the California Current System off Baja California. J. Geophys. Res. (Oceans) 120: 1173-1196.

Durazo R, Baumgartner TR. 2002. Evolution of oceanographic conditions off Baja California: 1997-1999. Prog. Oceanogr. 54: 7-31.

Durazo R, Ramírez-Manguilar AM, Miranda LE, Soto-Mardones L. 2010. Climatología de variables hidrográficas. In: GaxiolaCastro G, Durazo R (eds.), Dinámica del Ecosistema Pelágico Frente a Baja California, 1997-2007: Diez Años de Investigaciones Mexicanas de la Corriente de California. Secretaría de Medio Ambiente y Recursos Naturales, México, pp. $25-57$.

Félix-Uraga R, Alvarado-Castillo RM, Carmona-Piña R. 1996. The sardine fishery along the western coast of Baja California, 1981 to 1994. CalCOFI Rep. 37: 188-193.

Félix-Uraga R, Gómez-Muñoz VM, Quiñónez-Velázquez C, MeloBarrera FN, García-Franco W. 2004. On the existence of Pacific sardine groups off the west coast of Baja California and southern California. CalCOFI Rep. 45: 146-151.

Félix-Uraga R, Gómez-Muñoz VM, Quiñónez-Velázquez C, MeloBarrera FN, Hill K, García-Franco W. 2005. Pacific sardine (Sardinops sagax) stock discrimination off the west coast of Baja California and southern California using otolith morphometry. CalCOFI Rep. 46: 113-121.

Félix-Uraga R, Quiñónez-Velázquez C, Melo-Barrera FN, Hernández-Rivas ME, Torres-Palacios K, Molina-Carrasco FD. 2013. Sardine Fishery in Magdalena Bay, 2012-13. 14th Annual Meeting of the Trinational Sardine Forum, 5-6 December 2013, Ensenada, Baja California, Mexico.

Field DB, Baumgartner TR, Ferreira V, Gutierrez D, LozanoMontes H, Salvatteci R, Soutar A. 2009. Variability from scales in marine sediments and other historical records. In: Checkley D, Alheit J, Oozeki Y, Roy C (eds.), Climate Change and Small Pelagic Fish. Cambridge University Press, Cambridge, UK, pp. 45-63.

Fitch JE. 1969. Fossil records of certain schooling fishes of the California Current System. CalCOFI Rep. 13: 71-80.

García-Rodríguez FJ, García-Gasca SA, de la Cruz-Agüero J, CotaGómez VM. 2011. A study of the population structure of the Pacific sardine Sardinops sagax (Jenyns, 1842) in Mexico based on morphometric and genetic analyses. Fish. Res. 107: $169-176$.

Gluyas-Millán MG. 1994. Reproduction, age and length of first maturity of Pacific mackerel Scomber japonicus (Houttuyn, 1872) in Vizcaíno Bay. Cienc. Mar. 20: 409-419.

Hammann MG, Nevárez-Martínez MO, Green-Ruíz Y. 1998. Spawning habitat of the Pacific sardine (Sardinops sagax) in the Gulf of California: Egg and larval distribution 1956-1957 and 1971-1991. CalCOFI Rep. 39: 169-179.

Hedgecock D. 1986. Recognizing subpopulations in California's mixed pelagic fish stocks. In: Hedgecock D (ed.), Identifying Fish Subpopulations. Proceedings of a California Sea Grant Workshop: 27 January 1984. California Sea Grant College
Program, Institute of Marine Resources, University of California, La Jolla, CA, pp. 26-31.

Hsieh C, Reiss CS, Hunter JR, Beddington JR, May RM, Sugihara G. 2006. Fishing elevates variability in the abundance of exploited species. Nature 443: 859-862.

Kaplan IC, Brown CJ, Fulton EA, Gray IA, Field JC, Smith ADM. 2013. Impacts of depleting forage species in the California Current. Environ. Conserv. 40: 380-393.

Kelley JC. 1976. Sampling the sea. In: Cushing DH, Walsh JJ (eds.), The Ecology of the Seas. WB Saunders, Philadelphia, PA, pp. 361-387.

King JR, Agostini VN, Harvey CJ, McFarlane G, Foreman MGG, Overland JE, di Lorenzo E, Bond N, Aydin KY. 2011. Climate forcing and the California Current ecosystem. ICES J. Mar. Sci. 68: 1199-1216.

Kramer D. 1969. Synopsis of the biological data on the Pacific mackerel, Scomber japonicus, Houttuyn (Northeast Pacific). FAO Species Synopsis no. 40, Circular 302. Washington, D.C. $18 \mathrm{pp}$.

Kug J-S, Jin F-F, An S-I. 2009. Two types of El Niño events: Cold tongue El Niño and warm pool El Niño. J. Clim. 22: 1499-1515.

Kurian J, Colas F, Capet X, McWilliams JC, Chelton DB. 2011. Eddy properties in the California Current System. J. Geophys. Res. (Oceans) 116: 1-18.

Landry MR, Ohman MD, Goericke R, Stukel MR, Barbeau K, Bundy R, Kahru M. 2012. Pelagic community responses to a deep-water front in the California Current Ecosystem: Overview of the A-Front Study. J. Plankton Res. 34: 739-748.

Lasker R. 1985. An egg production method for estimating spawning biomass of northern anchovy, Engraulis mordax. US Dept. Commer., NOAA Tech. Rep. NMFS 36, 99 pp.

Lavaniegos BE. 2009. Influence of a multiyear event of low salinity on the zooplankton from Mexican eco-regions of the California Current. Prog. Oceanogr. 83: 369-375.

Lecomte F, Grant WS, Dodson JJ, Rodríguez-Sánchez R, Bowen BW. 2004. Living with uncertainty: Genetic imprints of climate shifts in East Pacific anchovy (Engraulis mordax) and sardine (Sardinops sagax). Mol. Ecol. 13: 2169-2182.

Leggett WC, Frank KT. 2008. Paradigms in fisheries oceanography. Oceanogr. Mar. Biol. Annu. Rev. 46: 331-363.

Lo NCH, Green-Ruiz YA, Cervantes M, Moser HG, Lynn RJ. 1996. Egg production and spawning biomass of Pacific sardine (Sardinops sagax) in 1994, determined by the daily egg production method. CalCOFI Rep. 37: 160-174.

Lo NCH, Macewicz BJ, Griffith DA. 2005. Spawning biomass of Pacific sardine (Sardinops sagax), from 1994-2004 off California. CalCOFI Rep. 46: 93.

Lo NCH, Dorval E, Funes-Rodríguez R, Hernández-Rivas ME, Huang Y, Fan Z. 2010a. Utilities of larval densities of Pacific mackerel (Scomber japonicus) off California, USA, and west coast of Mexico from 1951 to 2008, as spawning biomass indices. Cienc. Pesq. 18: 59-76.

Lo NCH, Macewicz BJ, Griffith DA. 2010b. Biomass and reproduction of Pacific sardine (Sardinops sagax) off the Pacific northwestern United States. Fish. Bull. 108: 174-192.

Logerwell E, Smith P. 2001. Mesoscale eddies and survival of late stage Pacific sardine (Sardinops sagax) larvae. Fish. Oceanogr. 10: $13-25$.

Love RH. 2012. Pacific sardine characteristics affecting the conduct of an acoustic clutter experiment off the West Coast of the United States. The Office of Naval Research. Technical Report May 2011-May 2012. Bayou Acoustics, Abita Springs, LA, $33 \mathrm{pp}$. 
Lluch-Belda D, Crawford RJM, Kawasaki T, MacCall AD, Parrish RH, Schwartzlose RA, Smith PE. 1989. World-wide fluctuations of sardine and anchovy stocks: The regime problem. S. Afr. J. Mar. Sci. 8: 195-205.

Lluch-Belda D, Lluch-Cota DB, Hernandez-Vazquez S, SalinasZavala CA, Schwartzlose RA. 1991. Sardine and anchovy spawning as related to temperature and upwelling in the California Current System. CalCOFI Rep. 32: 105-111.

Lynn RJ. 2003. Variability in the spawning habitat of Pacific sardine (Sardinops sagax) off southern and central California. Fish. Oceanogr. 12: 541-553.

Lynn RJ, Simpson JJ. 1987. The California Current System: The seasonal variability of its physical characteristics. J. Geophys. Res. 92: 12947-12966.

MacCall AD. 1979. Population estimates for the waning years of the Pacific sardine fishery. CalCOFI Rep. 20: 72-82.

MacCall AD. 1986. Review of the biological rationale for identifying subpopulations in fisheries. In: Hedgecock D (ed.), Identifying Fish Subpopulations. Proceedings of a California Sea Grant Workshop: 27 January 1984. California Sea Grant College Program, Institute of Marine Resources, University of California, La Jolla, CA, pp. 9-13.

MacCall AD. 2009. Mechanisms of low-frequency fluctuations in sardine and anchovy populations. In: Checkley D, Alheit J, Oozeki Y, Claude R (eds.), Climate Change and Small Pelagic Fish. Cambridge University Press, Cambridge, UK, pp. 285-299.

MacCall AD, Stauffer GD. 1983. Biology and fishery potential of jack mackerel (Trachurus symmetricus). CalCOFI Rep. XXIV: 46-56.

Macewicz BJ, Hunter JR. 1993. Spawning frequency and batch fecundity of jack mackerel, Trachurus symmetricus, off California during 1991. CalCOFI Rep. 34: 112-121.

Mackas DL. 2006. Interdisciplinary oceanography of the western North American continental margin: Vancouver Island to the tip of Baja California. In: Robinson AR, Brink KH (eds.), The Global Coastal Ocean: Interdisciplinary Regional Studies and Syntheses. Harvard University Press, pp. 441-501.

MacFarlane G, Beamish RJ 2001. The re-occurrence of sardines off British Columbia characterizes the dynamic nature of regimes. Prog. Oceanogr. 49:151-165.

McFarlane G, MacDougall L, Schweigert J, Hrabok C. 2005. Distribution and biology of Pacific sardines (Sardinops sagax) off British Columbia, Canada. CalCOFI Rep. 46: 144-160.

McFarlane G, Schweigert J, Detering J, Hodes V. 2010. Diet analysis of Pacific sardine (Sardinops sagax) off the west coast of Vancouver Island, British Columbia from 1997 to 2008. CalCOFI Rep. 51: 169-181.

Mantua NJ, Hare SR, Zhang Y, Wallace JM, Francis RC. 1997. A Pacific interdecadal climate oscillation with impacts on salmon production. Bull. Am. Meteorol. Soc. 78: 1069-1079.

Marr JC. 1960. The causes of major variations in the catch of the Pacific sardine, Sardinops caerulea (Girard). In: Rosa J, Murphy G (eds.), Proceedings of the World Scientific Meeting on the Biology of Sardines and Related Species. Food and Agriculture Organization of the United Nations, Rome, pp. 667-791

Moser H. 1996. The early stages of fishes in the California Current region. CalCOFI Atlas no. 33. Allen Press, Lawrence, KS, $1505 \mathrm{pp}$.

Nelson CS. 1977. Wind stress and wind stress curl over the California Current. Technical Report, NMFS-NOAA, Monterey, $\mathrm{CA}, 87 \mathrm{pp}$.

Nevárez-Martínez MO, Martínez-Zavala, MA, Cotero-Altamirano CE, Jacob-Cervantes ML, Green-Ruiz Y, Gluyas-Millán G,
Cota-Villavicencio A, Santos-Molina JP. 2006. Peces pelágicos menores. In: Arreguín-Sánchez F, Beléndez-Moreno L, Méndez Gómez-Humaran I, Solana-Sansores R, Rangel-Dávalos C (eds.), Sustentabilidad y Pesca Responsable en México. Evaluación y Manejo. Instituto Nacional de la Pesca, México, pp. 265-301.

Nieto K, McClatchie S, Weber ED, Lennert-Cody CE. 2014. Effect of mesoscale eddies and streamers on sardine spawning habitat and recruitment success off southern and central California. J. Geophys. Res. (Oceans) 119: 1-10.

[PFMC] Pacific Fishery Management Council. 1998. Amendment 8 (to the northern anchovy fishery management plan) incorporating a name change to: the coastal pelagic species fishery management plan. Technical Report, Pacific Fishery Management Council, Portland, Oregon, 39 pp.

Parrish RH, MacCall AD. 1978. Climatic variation and exploitation in the Pacific mackerel fishery. Fish. Bull. 167: 1-110.

Parrish RH, Nelson CS, Bakun A. 1981. Transport mechanisms and reproductive success of fishes in the California Current. Biol. Oceanogr. 1: 175-203.

Parrish RH, Serra R, Grant WS. 1989. The monotypic sardines, Sardina and Sardinops: Their taxonomy, distribution, stock structure, and zoogeography. Can. J. Fish. Aquat. Sci. 46: 2019-2036.

Peck MA, Reglero P, Takahashi M, Catalán IA. 2013. Life cycle ecophysiology of small pelagic fish and climate-driven changes in populations. Prog. Oceanogr. 116: 220-245.

[PICES] North Pacific Marine Science Organization. 1993. Part 1. Coastal pelagic fishes (report of Working Group 3) In: Hunter JR, Wada T (eds.), PICES Scientific Report no. 1-1993. North Pacific Marine Science Organization, Sidney B.C., Canada, pp. 1-24.

Radovich J. 1982. The collapse of the California sardine fishery. CalCOFI Rep. XXIII: 56-77.

Rodríguez-Sánchez R, Lluch-Belda D, Villalobos H, Ortega-García S. 2001. Large-scale long-term variability of small pelagic fish in the California Current System. In: Kruse GH, Bez N, Booth A, Dorn MW, Hills S, Lipcius RN, Pelletier D, Roy C, Smith SJ, Witherell D (eds.), Spatial Processes and Management of Fish Populations. University of Alaska Sea Grant AK-SG-01-02, Fairbanks, Alaska, pp. 447-462.

Rodríguez-Sánchez R, Lluch-Belda D, Villalobos H, Ortega-García S. 2002. Dynamic geography of small pelagic fish populations in the California Current System on the regime time scale (1931-1997). Can. J. Fish. Aquat. Sci. 59: 1980-1988.

Rykaczewski RR, Checkley DM. 2008. Influence of ocean winds on the pelagic ecosystem in upwelling regions. Proc. Natl. Acad. Sci. 105: 1965-1970.

[SAGARPA] Secretaría de Agricultura, Ganadería, Desarrollo Rural, Pesca y Alimentación. 2012. Plan de manejo pesquero para la pesquería de pelágicos menores (sardinas, anchovetas, macarelas y afines) del noroeste de México. SAGARPA, 54 pp.

Schwartzlose RA, Alheit J, Bakun A, Baumgartner TR, Cloete R, Crawford RJM, Fletcher WJ, Green-Ruiz Y, Hagen E, Kawasaki T, Lluch-Belda D, Lluch-Cota SE, MacCall AD, Matsuura Y, Nevárez-Martínez MO, Parrish RH, Roy C, Serra R, Shust KV, Ward MN, Zuzunaga JZ. 1999. Worldwide large-scale fluctuations of sardine and anchovy populations. S. Afr. J. Mar. Sci. 21: 289-347.

Smith PE. 2005. A history of proposals for subpopulation structure in the Pacific sardine (Sardinops sagax) population off western North America. CalCOFI Rep. 46: 75-82.

Song H, Miller AJ, McClatchie S, Weber ED, Nieto KM, Checkley DM. 2012. Application of a data-assimilation model to variability of Pacific sardine spawning and survivor habitats 
with ENSO in the California Current System. J. Geophys. Res. (Oceans) 117: 1-15.

Stepien CA, Rosenblatt RH. 1996. Genetic divergence in antitropical pelagic marine fishes (Trachurus, Merluccius, and Scomber) between North and South America. Copeia 3: 586-598.

Torres-Villegas JR. 2012. Gestión de la pesquería de los peces pelágicos menores de Baja California Sur: Propuesta de plan de manejo. Comité Estatal Sistema Producto Pelágicos Menores de Baja California Sur A.C., La Paz, 58 pp.

[U.S. GLOBEC] U.S. Global Ocean Ecosystems Dynamics. 1994. Eastern Boundary Current Program: A Science Plan for the California Current. Report no. 11, Berkeley, CA, 134 pp.

Valle-Rubio S. 2007. Variabilidad natural en la microquímica de otolitos de estadios tempranos de Sardinops sagax caeruleus. $\mathrm{PhD}$ thesis, Centro de Investigación Científica y de Educación Superior de Ensenada, Ensenada, México, 174 pp.

Van der Lingen CD, Castro L, Drapeau L, Checkley DMJ. 2005. Report of a GLOBEC-SPACC workshop on characterizing and comparing the spawning habitats of small pelagic fish. GLOBEC Rep. 21: 107 pp.

Van der Lingen CD, Bertrand A, Bode A, Brodeur R, Cubillos LA, Espinoza P, Friedland K, Garrido S, Irigoien X, Miller T, Möllmann C, Rodriguez-Sanchez R, Tanaka H, Temming A.
2009. Trophic dynamics. In: Checkley D, Alheit J, Oozeki Y, Roy C (eds.), Climate Change and Small Pelagic Fish. Cambridge University Press, Cambridge, UK, pp. 112-157.

Yaragina NA, Marshall CT. 2000. Trophic influences on interannual and seasonal variation in the liver condition index of Northeast Arctic cod (Gadus morhua). ICES J. Mar. Sci. 57: 42-55.

Weber ED, McClatchie S. 2012. Effect of environmental conditions on the distribution of Pacific mackerel (Scomber japonicus) larvae in the California Current System. Fish. Bull. 110: 85-97.

Zaitsev O, Trasviña-Castro A, Linero-Cueto J, Gaxiola-Castro G, Cepeda-Morales J. 2014. Oceanographic conditions over the continental shelf off Magdalena Bay (Mexico) in 2011-2012. Cienc. Mar. 40: 89-112. http://dx.doi.org/10.7773/cm.v40i2.2314

Zwolinski JP, Demer DA. 2012. A cold oceanographic regime with high exploitation rates in the Northeast Pacific forecasts a collapse of the sardine stock. Proc. Natl. Acad. Sci. 109: 4175-4180.

Zwolinski JP, Demer DA. 2013. Measurements of natural mortality for Pacific sardine (Sardinops sagax). ICES J. Mar. Sci. 70: 1408-1415.

Zwolinski JP, Emmett RL, Demer DA. 2011. Predicting habitat to optimize sampling of Pacific sardine (Sardinops sagax). ICES J. Mar. Sci. 68: 867-879.

Received August 2015, accepted November 2015. 